\title{
Metaluminous pyroxene-bearing granulite xenoliths from the lower continental crust in central Spain: their role in the genesis of Hercynian I-type granites
}

\author{
CARløS VILLASECA ${ }^{1, *}$, DAVID OREJANA ${ }^{1}$, BRUCE A. PATERSON ${ }^{2}$, KJELL BILLSTROM $^{3}$ and CECILIA \\ PÉREZ-SOBA ${ }^{1}$ \\ ${ }^{1}$ Departamento de Petrología y Geoquímica, Universidad Complutense, 28040, Madrid, Spain \\ *Corresponding author, e-mail: granito@geo.ucm.es \\ ${ }^{2}$ Department of Earth Sciences, University of Bristol, BS8 1RJ, Bristol, UK \\ ${ }^{3}$ Swedish Museum of Natural History of Stockholm, Sweden
}

\begin{abstract}
Basic and intermediate meta-igneous xenoliths are very scarce within the granulite population ransported by the Permian alkaline lamprophyric dyke swarm of the Spanish Central System (SCS). These xenoliths are metaluminous pyroxene-bearing charnockites (sensu lat•). They show LREE-poor plagioclase and orthopyroxene-clinopyroxene. Crystallization conditions were estimated at about 850 to $1000^{\circ} \mathrm{C}$ and 9 to $11 \mathrm{kbar}$, a slightly higher range than that estimated for the associated peraluminous granulites, but indicating derivation from the lowermost crust.

Whole-rock geochemistry suggests that the charnockite samples are not a cogenetic suite. The more basic varieties have affinities with cumulates from previous calc-alkaline underplated protoliths, whereas intermediate chamockites have a restitic origin. The similarity in $\mathrm{Sr}-\mathrm{Nd}-\mathrm{Pb}$ isotopic signatures between these restitic charnockites and some SCS I-type granites suggests a genetic relationship. This study, including $\mathrm{Pb}$ isotopic data from the whole granulite xenolith suite, reinforces the lower-crustal derivation of the SCS Hercynian granitic batholith.
\end{abstract}

Key-words: granulite xenoliths, pyroxene mineral chemistry, Hercynian granites, igneous perology, lower crust, central Spain.

\section{Introduction}

The Spanish Central System (SCS) is a moderate-elevation mountain range ( $1400 \mathrm{~m}$ mean elevation) composed mainly of granitic plutons intruded into felsic (meta-granitic and metasedimentary) Palaeozoic and Neoproterozoic continental crust. This large Hercynian batholith is dominated by peraluminous S-type granites, although some minor weakly peraluminous or metaluminous granites of I-type affinity also occur (Villaseca et $\boldsymbol{a l . , 1 9 9 8 ; ~ B e a ~ e t ~} \boldsymbol{a l . , 1 9 9 9 ) . ~}$ The origin of these granites is controversial, concerning the roles of crustal and mantle contribution, especially for I-type granites (e.g. Moreno Ventas et $\boldsymbol{a l}$., 1995; Villaseca et al., 1998; Bea et al., 1999).

Upper Permian alkaline lamprophyric dyke swarms cross-cut both granite and basement rocks. They contain abundant deep crustal xenoliths of variable compositions. Studies of lower crustal granulite xenoliths from these alkaline lamprophyres have revitalised the discussion regarding a prevalently crustal origin for the SCS batholith vs. involvement of significant mantle-derived magmas. The peraluminous granulite xenolith suite matches the residual composition (major and trace elements, and Sr-Nd$\mathrm{O}$ isotopic ratios) of the outcropping granitic intrusions
(Villaseca et al., 1999; Villaseca \& Herreros, 2000). This hypothesis is corroborated by geochronological data that show the residual granulites are of Hercynian age, i.e. their granulitic imprint was acquired during late-Hercynian times (320 to $285 \mathrm{Ma}$ ), identical to the intrusion ages for the SCS plutons (Fernández Suárez et al., 2006). Thus the lower crustal granulite suite of xenoliths seems to represent the residual keel of SCS granites.

In this work we describe pyroxene-bearing mafic and intermediate granulites from the lower crustal xenolith suite that have not been previously studied. These samples comprise around 1 vol.\% of the entire xenolith population. We present geochemical data for the whole xenolith suite, trace element microanalysis of major minerals and whole-rock $\mathrm{Sr}-\mathrm{Nd}-\mathrm{Pb}$ isotope ratios and discuss their implications in the genesis of the SCS Hercynian granites.

\section{Geological setting and xenolith petrography}

The SCS Hercynian batholith is made by the coalescence of more than a hundred plutons in an age range of around 324 to $285 \mathrm{Ma}$ (Villaseca \& Herreros, 2000). Two main granite 


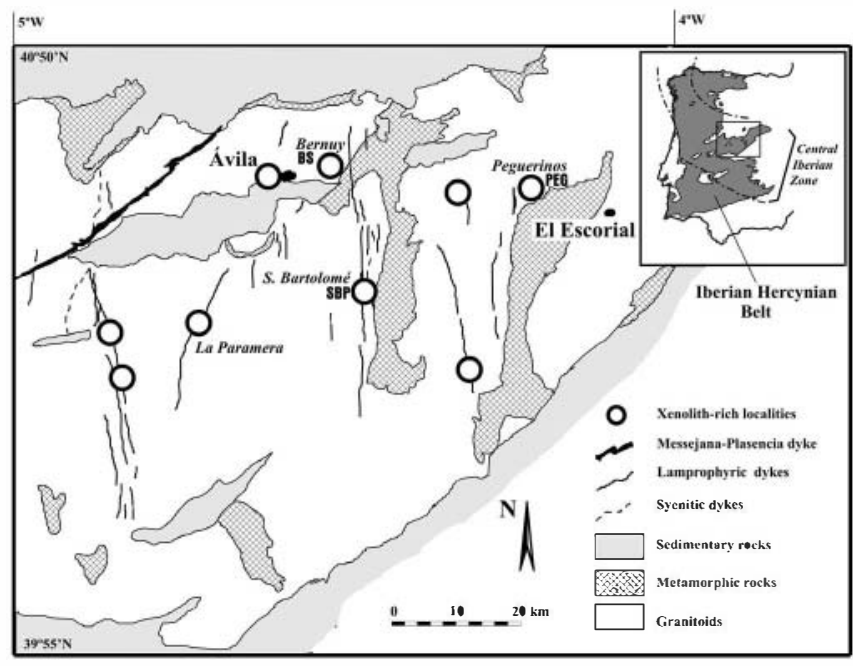

Fig. 1. Geological sketch of the Spanish Central System (SCS) showing the main outcrops where granulite xenoliths are found within the host Permian alkaline lamprophyres and diabases. Localities with complex xenolith population are indicated: BS: Bernuy Salinero, PEG: Peguerinos, SBP: San Bartolomé de Pinares.

types have been distinguished: i) peraluminous cordieritebearing granites of S-type affinity, and ii) metaluminous to weakly peraluminous biotite-bearing granites with locally accessory amounts of amphibole, described as I-type granites (e.g. Villaseca et al., 1998). Intermediate granite types without characteristic peraluminous minerals have been also described (e.g. Pinarelli \& Rottura, 1995). Much debate on SCS granite is related to the relative roles of mantle and crust during their genesis. Some studies suggest a mixed mantle-crustal source for granites (Pinarelli \& Rottura, 1995; Moreno-Ventas et al., 1995; Castro et al., 1999) whereas others point to a mainly lower crustal origin (Villaseca et al., 1998, 1999; Bea et al., 1999). The SCS batholith is later intruded by different suites of postcollisional dyke swarms (Villaseca et al. 2004): 1) E-W oriented calc-alkaline microdiorites and later shoshonitic microgabbros, all accompanied by abundant coeval granite porphyries, 2) N-S oriented alkaline lamprophyre dykes, and 3) the gabbroic Messejana-Plasencia tholeiitic dyke, the last magmatic event registered in the SCS (dated at $203 \mathrm{Ma}$, Dunn et al., 1998), which has been related to the opening of the Atlantic Ocean. Only the lamprophyre dykes carry deep xenoliths of variable composition.

Lamprophyres have been dated to Upper Permian times (264 to 252 Ma, Perini et al., 2004; Fernández Suárez et al., 2006) and locally were emplaced as diatremelike, xenolith-rich subvolcanic bodies (Nuez et al., 1982; Villaseca et al., 1999; Bea et al., 1999). The xenolith localities are shown in Fig. 1. The abundance of xenolith types is detailed in Fig. 2 and their general characteristics are described in Table 1 . The data presented here double the population of studied xenoliths and enlarge the geographical area sampled, yielding a more representative characterization of the lower continental crust beneath the SCS. The relative abundance of the three main types of granulite xenoliths distinguished by Villaseca et $a l$.

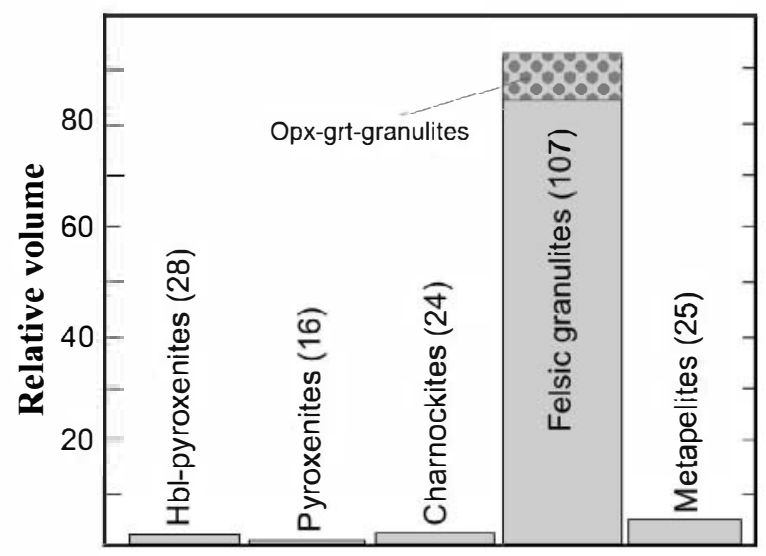

Fig. 2. Lithologic types and abundance of sampled xenoliths (granulites and ultramafic xenoliths) from the SCS alkaline dykes based on their relative abundances. In brackets the number of samples for each group is shown.

(1999) is confirmed by this expanded sampling: i) a major population of meta-igneous felsic peraluminous garnetbearing granulites (approx. $93 \mathrm{vol} . \%$ of the total xenolith suite, Fig. 2), including some orthopyroxene-garnetbearing varieties (Villaseca et al., 1999), ii) metapelites or highly peraluminous garnet-sillimanite-rich granulites (approx. 5 vol.\%) of pelitic origin (Villaseca et al., 1999), and iii) charnockites or metaluminous pyroxene-bearing granulites (approx. 1 vol.\%). The latter are the main object of this work. Although the SCS xenolith suite consists mainly of granulite crustal xenoliths, there are some minor ultramafic and related mafic xenoliths (pyroxenites and hornblenditic pyroxenites) formed mainly during the alkaline underplating event which gave rise to the lamprophyre dyke swarms (Orejana et al., 2006). The different granulite types coexist in most of the xenolith-rich outcrops, sometimes even in the same thin-section. In three localities (BS, SBP and PEG, Fig. 1), granulite xenoliths are found together with pyroxenitic ulramafic-mafic xenoliths (Orejana et al., 2006).

Pyroxene-bearing granulites may have orthopyroxene, clinopyroxene or both; they form small rounded xenoliths rarely exceeding $5 \mathrm{~cm}$ in maximum length. They show a granoblastic texture with no clear evidence of banding likely due to their small size. They are rich in felsic minerals; quartz, K-feldspar and/or plagioclase usually exceeds $50 \%$ in modal amount (Table 1). They plot in the quartz-monzogabbroic (enderbite-jotunite) to gabbroic (norite) modal fields (Fig. 3). Although the marked dominance of plagioclase among felsic minerals prevents their classification as charnockites s.s., this name will be used informally through the text to refer to these metaluminous pyroxene-bearing xenoliths.

SCS charnockite mineralogy comprises plagioclase, quartz, K-feldspar, orthopyroxene and clinopyroxene as major phases. Peraluminous minerals (sillimanite, garnet, Al-phlogopite) are lacking, in contrast with the other two coexisting groups of lower crustal granulite xenoliths (Villaseca et al. 1999). Accessory phases include rutile, sphene, apatite, ilmenite, zircon and pyrrhotite. 
Table 1. Xenolith types in the Permian SCS alkaline lamprophyres.

\begin{tabular}{|c|c|c|c|c|}
\hline Sample & Mineralogy (modal amount in vol.\%) & Texture & Size & (Composition) Nature \\
\hline & Hornblenditic pyroxenites & & & Ultrabasic-Basic \\
\hline 103489 & amph (40), cpx (40), pl (13), ap (3), spl (2), anl (2), cc & igneous & $1-2 \mathrm{~cm}$ & Alkaline ultramafic cumulate (Orejana et al., 2006) \\
\hline \multirow[t]{2}{*}{104389} & cpx (69), amph (15), pl (10), phl (3), anl (1), ap, spl, cc & igneous & $0.5-1.5 \mathrm{~cm}$ & “ \\
\hline & Pyroxenites s.l. & & & Ultrabasic-Basic \\
\hline 101892 & Clinopyroxenite: $\mathrm{cpx}(94), \mathrm{spl}(6)$ & cataclastic & $<0.5 \mathrm{~cm}$ & Alkaline? ultramafic cumulate (Orejana et al., 2006) \\
\hline 102131 & Websterite: $\mathrm{cpx}(57)$, opx (42), spl (1) & granoblastic & $<0.5 \mathrm{~cm}$ & calc-alkaline ultramafic cumulate (Orejana et al., 2006) \\
\hline 104395 & Charnockites s.l. (Type 1 of VDPB-99) & & & Basic-intermediate, metaluminous (meta-igneous rocks) \\
\hline $103490 B$ & pl (83), opx (16), ilm (1), zrn, ap & granoblastic & $1 \mathrm{~cm}$ & residual granulite (this work) \\
\hline 105775 & $\mathrm{pl}(58), \mathrm{cpx}(23), \mathrm{opx} ?(12), \mathrm{rt}(2)$, ap & granoblastic & $1.5 \mathrm{~cm}$ & calc-alkaline cumulate (this work) \\
\hline 105779 & pl (80), cpx (16), ilm (2), ap, zrn, spn, cc & granoblastic & $1 \mathrm{~cm}$ & residual granulite (this work) \\
\hline $\mathrm{U}-28$ & $\mathrm{pl}(64)$, opx (29), cpx (5), rt, ap, zm, ilm & granoblastic & $1 \mathrm{~cm}$ & " \\
\hline \multirow[t]{2}{*}{ U-3 } & pl (54), qtz (17), kfs (17), opx (10), ap (1), zm, ilm & granoblastic & $2.5 \mathrm{~cm}$ & “ \\
\hline & Felsic granulites (Type 2 of VDPB-99) & & & \\
\hline 103184 & pl (53), grt (28), opx (18), ilm (1), qtz, ap, zrn & granoblastic, banded & $1-5 \mathrm{~cm}$ & residual granulite (Villaseca et al., 1999) \\
\hline 81845 & kfs (47), pl (32), grt (10), opx (5), qtz (3), rt, ap, zrn, ilm & granoblastic & $2-3 \mathrm{~cm}$ & " \\
\hline \multirow[t]{2}{*}{105796} & pl (40), qtz (33), grt (22), opx (3), ilm (1), phl, ap, zrn & granoblastic, banded & $2-3 \mathrm{~cm}$ & “ \\
\hline & Felsic granulites ss (Type 2b) & & & Intermediate-acid, peraluminous (meta-igneous rocks) \\
\hline $\mathrm{U}-50$ & $\operatorname{grt}(40), \mathrm{kfs}(32), \mathrm{pl}(19), \mathrm{qtz}(3), \mathrm{phl}(1), \mathrm{rt}(1)$, ap, zm & granoblastic, banded & $10 \mathrm{~cm}$ & residual granulite (Villaseca et al., 1999) \\
\hline 95141 & kfs (55), qtz (24), grt (17), sil (3), rt (1), pl, ap, zrn & granoblastic, banded & $8-12 \mathrm{~cm}$ & “ \\
\hline \multirow[t]{2}{*}{99185} & qtz (37), $\mathrm{pl}^{*}(34), \operatorname{grt}(28), \mathrm{rt}(1), \mathrm{ap}, \mathrm{zm}, \mathrm{mnz}$ & granoblastic, banded & $6 \mathrm{~cm}$ & " \\
\hline & Metapelitic granulites (Type 3 of VDPB-99) & & & Highly peraluminous (meta-sedimentary rocks) \\
\hline 77750 & kfs (45), grt (22), qtz (18), sil (13), rt (1), ap, zrn, mnz & granoblastic, banded & $7-10 \mathrm{~cm}$ & residual granulite (Villaseca et al., 1999) \\
\hline U-90 & grt (38), pl (29), kfs (16), sil (11), rt (2), qtz (1), ap & granoblastic & $6 \mathrm{~cm}$ & “ \\
\hline 104550 & $\operatorname{grt}(71)$, sil (25), pl (3), rt (1), ilm, zrn & granoblastic & $4 \mathrm{~cm}$ & highly restitic granulite \\
\hline
\end{tabular}

VDPB-99 = Villaseca et al. (1999). Mineral abbreviations after Kretz (1983) except: amph = amphibole, pl* = ternary feldspar. Modal analyses of pyroxenite xenoliths from (Orejana et al., 2006), felsic and metapelitic granulites from (Villaseca et al., 1999).

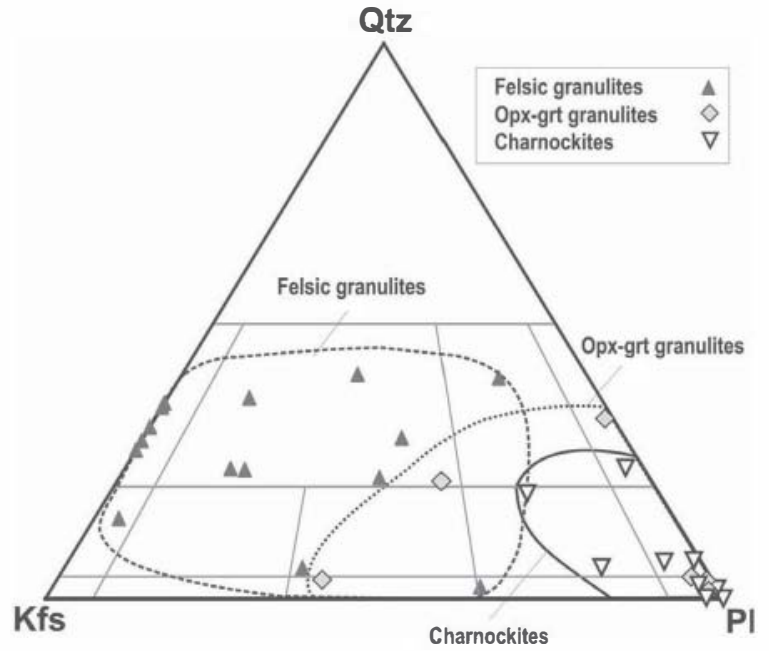

Fig. 3. Modal composition of the SCS granulite xenoliths in terms of Kfs-Qtz-Pl proportions.

The peraluminous orthopyroxene-garnet-(phlogopite)bearing granulites (type 2a from Villaseca et al., 1999) (Table 1) are more felsic in modal composition than the metaluminous charnockites (Fig. 3), and show different mineral and whole-rock chemical compositions, as it will be exposed below.

\section{Analytical methods}

Major element mineral composition was determined at the Centro de Microscopía Electrónica "Luis Bru" (Complutense University of Madrid) using a JEOL JZA-8900M electron microprobe (EMP) with four wavelength dispersive spectrometers. Analyses were performed with an accelerating voltage of $15 \mathrm{kV}$ and an electron beam current of $20 \mathrm{nA}$, with a beam diameter of 2-5 $\mu \mathrm{m}$. Elements were counted for $10 \mathrm{~s}$ on the peak and $5 \mathrm{~s}$ on each of two background positions. Corrections were made using the ZAF method.

Concentrations of 24 trace elements (REE, Ba, Rb, Th, U, $\mathrm{Nb}, \mathrm{Ta}, \mathrm{Sr}, \mathrm{Zr}$, Hf and $\mathrm{Y}$ ) were determined on major mineral phases on $>130 \mu \mathrm{m}$ thick polished sections by laser ablation ICP-MS (LA-ICP-MS) at the Department of Earth Sciences (University of Bristol) using a VG LaserProbe II (266 nm frequency-quadrupled Nd-YAG laser) coupled to a VG Elemental PlasmaQuad 3 ICP-MS. The diameter of the laser spots was approximately $20-30 \mu \mathrm{m}$. The counting time for each analysis was typically $100 \mathrm{~s}(40 \mathrm{~s}$ measuring gas blank to establish the background and $60 \mathrm{~s}$ for the remainder of the analysis). The NIST 610 and 612 glass standards were used to calibrate relative element sensitivities for the analyses of the silicate minerals. Each laser analysis used $\mathrm{Si}$ (for feldspars and orthopyroxene) and $\mathrm{Ca}$ (for clinopyroxenes) as an internal standard, with concentrations determined by electron microprobe. Ti was the internal standard for rutile analyses. 
Table 2. Selected representative EMP analyses of feldspars from the SCS charnockite xenoliths.

\begin{tabular}{|c|c|c|c|c|c|c|c|c|c|c|c|c|}
\hline Sample & 102142 & $\mathrm{U}-3$ & U-3 & 102131 & 104390B & 104551 & 104867 & 105775 & 105775 & U-28 & U-28 & U-3 \\
\hline Analysis & 40 & 68 & 70 & 4 & 49 & 5 & 67 & 60 & 12 & 24 & 15 & 61 \\
\hline Mineral & Kfs & Kfs & Kfs & Plg & Plg & Plg & Plg & Plg & Plg & Plg & Plg & Plg \\
\hline $\mathrm{SiO}_{2}$ & 64.13 & 64.17 & 63.30 & 53.28 & 58.28 & 53.24 & 59.45 & 49.28 & 50.98 & 56.19 & 57.98 & 57.20 \\
\hline $\mathrm{TiO}_{2}$ & 0.03 & 0.07 & 0.00 & 0.06 & 0.04 & 0.03 & 0.01 & 0.08 & 0.08 & 0.02 & 0.01 & 0.01 \\
\hline $\mathrm{A}_{12} \mathrm{O}_{3}$ & 20.12 & 18.97 & 19.12 & 29.77 & 25.68 & 28.92 & 25.25 & 30.87 & 30.34 & 26.91 & 25.76 & 26.11 \\
\hline $\mathrm{FeO}$ & 0.01 & 0.11 & 0.00 & 0.09 & 0.09 & 0.21 & 0.18 & 0.23 & 0.28 & 0.15 & 0.16 & 0.10 \\
\hline $\mathrm{MnO}$ & 0.00 & 0.00 & 0.00 & 0.05 & 0.01 & 0.04 & 0.02 & 0.02 & 0.04 & 0.02 & 0.01 & 0.00 \\
\hline $\mathrm{MgO}$ & 0.00 & 0.00 & 0.03 & 0.06 & 0.02 & 0.05 & 0.03 & 0.10 & 0.08 & 0.04 & 0.04 & 0.00 \\
\hline $\mathrm{CaO}$ & 1.03 & 0.78 & 0.26 & 12.10 & 7.75 & 12.51 & 7.76 & 14.60 & 14.86 & 8.88 & 9.11 & 8.84 \\
\hline $\mathrm{Na}_{2} \mathrm{O}$ & 4.90 & 3.52 & 0.71 & 4.38 & 6.52 & 3.73 & 6.70 & 3.23 & 2.51 & 5.83 & 5.42 & 6.99 \\
\hline $\mathrm{K}_{2} \mathrm{O}$ & 8.51 & 12.28 & 15.41 & 0.43 & 1.02 & 0.93 & 1.03 & 0.27 & 0.28 & 1.15 & 1.21 & 1.47 \\
\hline $\mathrm{P}_{2} \mathrm{O}_{5}$ & 0.00 & 0.06 & 0.01 & 0.02 & 0.05 & 0.02 & 0.02 & n.d. & 0.04 & n.d. & 0.01 & 0.05 \\
\hline Total & 98.72 & 99.96 & 98.83 & 100.69 & 99.99 & 99.98 & 100.90 & 98.67 & 99.47 & 99.18 & 99.71 & 100.77 \\
\hline $\mathrm{Si}$ & 11.666 & 11.781 & 11.778 & 9.618 & 10.490 & 9.693 & 10.597 & 9.138 & 9.337 & 10.212 & 10.450 & 10.305 \\
\hline $\mathrm{Al}$ & 4.310 & 4.102 & 4.256 & 6.329 & 5.444 & 6.200 & 5.301 & 6.741 & 6.543 & 5.758 & 5.468 & 5.511 \\
\hline $\mathrm{Ti}$ & 0.005 & 0.010 & 0.000 & 0.008 & 0.005 & 0.004 & 0.001 & 0.012 & 0.010 & 0.003 & 0.001 & 0.002 \\
\hline $\mathrm{Fe}_{2}$ & 0.001 & 0.016 & 0.000 & 0.014 & 0.014 & 0.032 & 0.027 & 0.036 & 0.042 & 0.022 & 0.024 & 0.014 \\
\hline $\mathrm{Mn}$ & 0.000 & 0.000 & 0.000 & 0.008 & 0.002 & 0.006 & 0.003 & 0.003 & 0.006 & 0.002 & 0.002 & 0.000 \\
\hline $\mathrm{Mg}$ & 0.000 & 0.000 & 0.008 & 0.016 & 0.005 & 0.014 & 0.008 & 0.027 & 0.022 & 0.010 & 0.012 & 0.000 \\
\hline $\mathrm{Ca}$ & 0.201 & 0.154 & 0.053 & 2.340 & 1.495 & 2.440 & 1.482 & 2.901 & 2.916 & 1.730 & 1.760 & 1.697 \\
\hline $\mathrm{Na}$ & 1.729 & 1.254 & 0.262 & 1.533 & 2.276 & 1.317 & 2.316 & 1.161 & 0.890 & 2.053 & 1.895 & 2.430 \\
\hline K & 1.975 & 2.875 & 3.717 & 0.099 & 0.234 & 0.216 & 0.234 & 0.063 & 0.066 & 0.267 & 0.277 & 0.335 \\
\hline $\mathrm{P}$ & 0.000 & 0.010 & 0.000 & 0.000 & 0.010 & 0.000 & 0.000 & - & 0.010 & - & 0.000 & 0.010 \\
\hline Cations & 19.887 & 20.202 & 20.074 & 19.965 & 19.975 & 19.922 & 19.969 & 20.082 & 19.842 & 20.057 & 19.889 & 20.304 \\
\hline $\mathrm{Ab}$ & 44.30 & 29.30 & 6.50 & 38.60 & 56.80 & 33.10 & 57.40 & 28.10 & 23.00 & 50.70 & 48.20 & 54.50 \\
\hline An & 5.10 & 3.60 & 1.30 & 58.90 & 37.30 & 61.40 & 36.80 & 70.30 & 75.30 & 42.70 & 44.80 & 38.00 \\
\hline Or & 50.60 & 67.10 & 92.20 & 2.50 & 5.80 & 5.40 & 5.80 & 1.50 & 1.70 & 6.60 & 7.00 & 7.50 \\
\hline
\end{tabular}

Whole-rock major and trace element analyses of seven xenoliths (4 charnockites and 3 opx-grt-granulites) were determined at the CNRS-CRPG, Nancy. The samples were fused using $\mathrm{LiBO}_{2}$ and dissolved with $\mathrm{HNO}_{3}$. Solutions were analysed by inductively coupled plasma atomic emission spectrometry (ICP-AES) for major elements, whilst trace elements were determined by ICP mass spectrometry (ICP-MS). Uncertainties in major elements are generally between 1 and $3 \%$, except for $\mathrm{MnO}(5-10 \%)$ and $\mathrm{P}_{2} \mathrm{O}_{5}$ $(>10 \%)$, whereas most of the trace elements have uncertainties $<10 \%$. More information on the procedure, precision and accuracy of Nancy ICP-MS analyses is given by Carignan et al. (2001).

The same xenoliths were also selected for combined Sr-Nd isotopic analyses at the CAI de Geocronologia $y$ Geoquimica Isotópica of the Complutense University of Madrid, using an automated VG Sector 54 multicollector thermal ionisation mass spectrometer with data acquired in multidynamic mode. Isotopic ratios of $\mathrm{Sr}$ and Nd were measured on an aliquot of whole-rock powder. The Sr-Nd analytical procedures used in this laboratory have been described elsewhere (Reyes et al., 1997). Repeated analysis of NBS 987 gave ${ }^{87} \mathrm{Sr} /{ }^{86} \mathrm{Sr}=\mathbf{0 . 7 1 0 2 4 9} \pm 30$ $(2 \sigma, n=15)$ and for the JM Nd standard the ${ }^{143} \mathrm{Nd} /{ }^{144} \mathrm{Nd}=$ $0.511809 \pm 20(2 \sigma, n=13)$. The $2 \sigma$ error on calculated $\varepsilon(\mathrm{Nd})$ values is $\pm \mathbf{0 . 4}$.

Two charnockites, one opx-grt granulite and five other peraluminous granulite xenoliths were selected for $\mathrm{Pb}$ isotopic analyses at the Natural History Museum of Stock- holm University using a Finnigan MAT 261 TIMS with multicollector and a secondary electron multiplier. It was only possible to prepare K-feldspar separates from three of the peraluminous granulite xenoliths (Table 7 ). The $\mathrm{Pb}$ isotope composition of the two pyroxenite xenoliths of probable calc-alkaline affinity from Orejana et al. (2006) have been also studied for comparison. The samples were dissolved with $\mathrm{HF}$ and $\mathrm{HNO}_{3}$. A ${ }^{205} \mathrm{~Pb}$ spike was added to each sample. $\mathrm{Pb}$ was separated using cation exchange columns. The NBS 981 and 982 elemental Pb standards were used to evaluate fractionation and precision, the latter being around $0.1 \%$ for the isotopic ratios shown in Table 7. Repeated analyses of international standard BCR-1 were used to monitor accuracy.

\section{Mineral chemistry}

\section{Feldspars}

Representative EMP analyses of charnockite feldspars are shown in Table 2. K-feldspar always represents $<20$ vol.\% of the xenolith (Table 1). K-feldspar has a greater Or component in interstitial areas and in rims (Or95) than in inner zones $\left(\mathrm{Or}_{50-70}\right)$. Although their major element composition resembles that of feldspars from the SCS peraluminous granulite xenoliths, their $\mathrm{P}_{2} \mathrm{O}_{5}$ content is significantly lower, always $<\mathbf{0 . 0 6} \mathbf{w t} . \%$, and at least three times lower than feldspars in coexisting peraluminous types (Fig. 4b). 

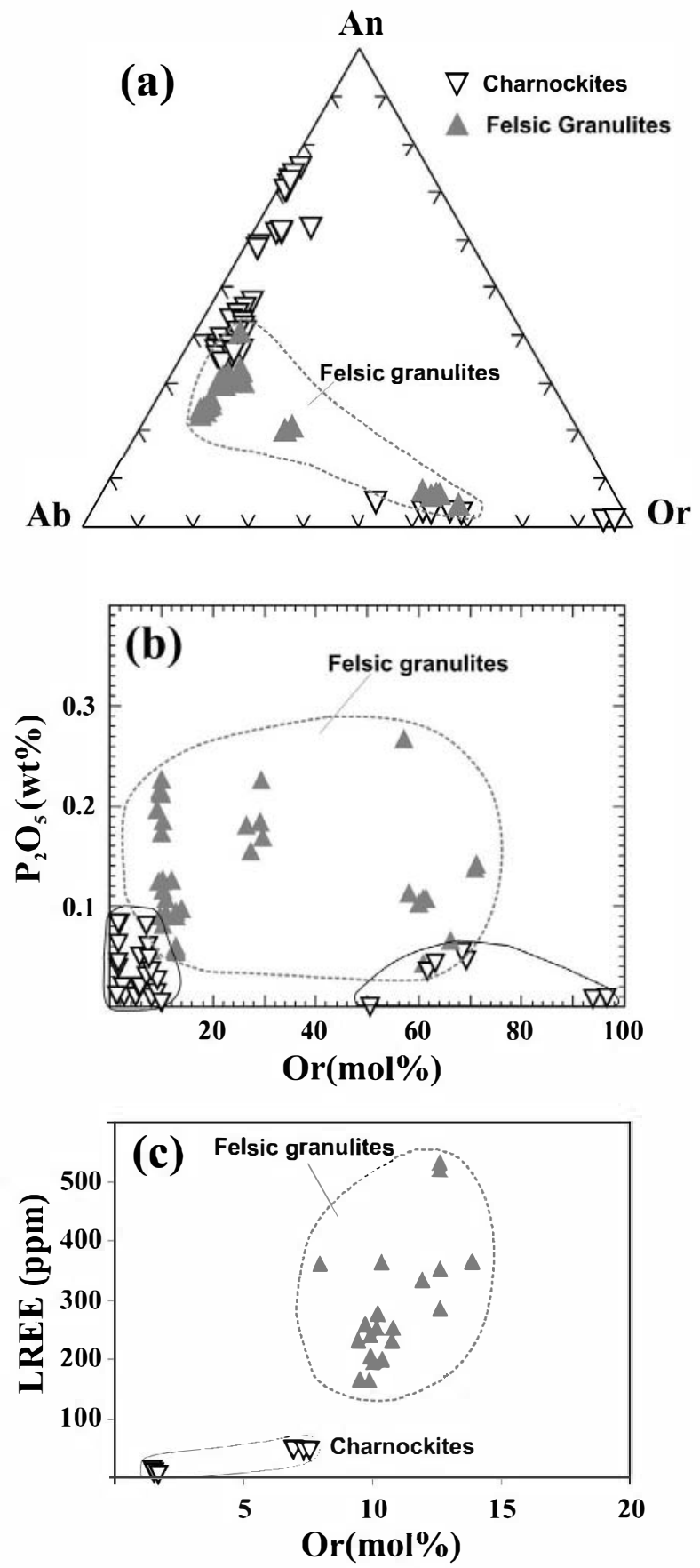

Fig. 4. Feldspar composition of SCS granulite xenoliths: a) Ternary Ab-An-Or diagram; b) Or $v s$. $\mathrm{P}_{2} \mathbf{\Theta}_{5}$; c) Or $v s$. total LREE contents.

Plagioclase is the most abundant mineral in the charnockites, ranging from 50 to $75 \mathrm{vol} . \%$ of the xenolith. Its composition varies between $A n_{37}$ to $A n_{73}$, being more Ca-rich than plagioclase from peraluminous xenoliths. Plagioclase in the charnockites is also lower in $\mathrm{K}_{2} \mathrm{O}(\mathrm{Or}<10 \mathrm{~mol} \%)$ and $\mathrm{P}_{2} \mathrm{O}_{5}(<\mathbf{0 . 1}$ wt.\%) contents (Fig. 4) compared to the peraluminous xenoliths.

Major differences are apparent when the trace element contents of feldspars are considered. Plagioclase in the charnockites have low LREE contents, in the range of 7
$50 \mathrm{ppm}$ (Table 2), as is common in metaluminous granulites (Pride \& Muecke, 1981; Loock et al., 1990), whereas plagioclases in SCS peraluminous granulites show much higher LREE contents, in the range of $150-550 \mathrm{ppm}$ (Villaseca et al., 2003) (Fig. 4c). Other lower crustal granulite xenoliths of peraluminous composition also have LREE-rich plagioclases (Reid, 1990; Condie et al., 2004), similarly to those of SCS felsic meta-igneous xenoliths (Villaseca et al., 2007). Charnockite plagioclase also shows slightly lower $\mathrm{Rb}-\mathrm{Ba}-(\mathrm{Sr})$ contents than plagioclase from peraluminous granulites.

\section{Pyroxenes}

SCS pyroxene-bearing granulites typically contain 10$40 \mathrm{vol} \%$ orthopyroxene, clinopyroxene or both, always subordinate to modal plagioclase (Table 1). Pyroxene is the only mafic phase in these xenoliths. Pyroxenes are chemically varied suggesting that the granulites are compositionally heterogeneous; orthopyroxene ranges from $E_{76}$ to $\mathrm{En}_{43}$ and is richer in Wo (1-3\%) than orthopyroxenes from peraluminous opx-grt-granulites. In contrast, orthopyroxenes from these peraluminous granulites have a more restricted compositional range ( $\mathrm{En}_{61}$ to $\mathrm{En}_{45}$, Table 3$)$. The high $\mathrm{CaO}\left(0.5\right.$ to 1.2 wt.\%) and low $\mathrm{Al}_{2} \mathrm{O}_{3}$ contents (1.4 to $6 \mathrm{wt} . \%$ ) of charnockite orthopyroxenes distinguish them from peraluminous granulite orthopyroxenes (Fig. 5a).

Clinopyroxene only appears in charnockites within the SCS xenolith suite. XMg in clinopyroxene varies from $\mathbf{0 . 8 0}$ to 0.68 with variable $\mathrm{CaO}$ (18.4 to 24.6 wt.\%) and $\mathrm{Al}_{2} \mathrm{O}_{3}$ (mostly from 1.6 to 4.3 wt.\%) contents (Fig. 5b). In one granulite, that is located in the same sample (102131) of the only websterite xenolith found in the SCS lamprophyres (Orejana et al., 2006), clinopyroxene shows high $\mathrm{Na}_{2} \mathrm{O}$ (up to 1.1 wt.\%) and $\mathrm{Al}_{2} \mathrm{O}_{3}$ (up to 8.3 wt.\%) contents, equivalent to $8.2 \mathrm{~mol} \%$ jadeite. In all cases, bar the previously mentioned granulite 102131 , granulitic clinopyroxenes show lower $\mathrm{TiO}_{2}, \mathrm{Cr}_{2} \mathrm{O}_{3}, \mathrm{NiO}, \mathrm{Na}_{2} \mathrm{O}$ and $\mathrm{Al}_{2} \mathrm{O}_{3}$ contents when compared to clinopyroxene from SCS ultramafic xenoliths (Fig. 5b).

Orthopyroxene shows much lower trace element concentrations than clinopyroxene. Orthopyroxene in SCS metaluminous granulites show higher $\mathrm{Sc}, \mathrm{Cr}, \mathrm{Y}$, and HREE contents than those from garnet-bearing peraluminous types; however the latter are notably richer in V (Table 4). Moreover, their chondrite-normalized REE patterns display a marked positive HREE fractionation $\left(G \mathbf{d}_{N} / \mathrm{Er}_{\mathrm{N}}=0.3\right)$ whereas orthopyroxene from peraluminous opx-grt granulites show a negative HREE fractionation $\left(\mathrm{G} \mathbf{d}_{N} / \mathrm{Er}_{\mathrm{N}}=\right.$ 3.5) (Fig. 6a). There are also remarkably similar trace element composition and REE patterns in the orthopyroxenes from the two-pyroxene granulite and the websterite (Fig. 6a), both from the same sample 102131.

Clinopyroxene shows a more variable trace element composition. In sample 105775 clinopyroxene has higher YHREE contents than clinopyroxene from ultramafic pyroxenites (Fig. 6b). The charnockite clinopyroxene has lower LILE ( $\mathrm{Rb}, \mathrm{Sr}, \mathrm{Ba})$, HFSE (Nb, Th, Zr, Hf, Ta) and LREE contents than clinopyroxene from SCS ultramafic xeno- 
Table 3. Selected representative EMP analyses of pyroxenes from the SCS charnockite xenoliths.

\begin{tabular}{|c|c|c|c|c|c|c|c|c|c|c|c|c|}
\hline Sample & $105796^{*}$ & 103490B & 104867 & U-3 & 102131 & $\mathrm{U} 28$ & $\mathrm{U} 28$ & 102131 & 102142 & 104551 & 105775 & 105779 \\
\hline Analysis & 52 & 32 & 73 & 54 & 6 & 18 & 17 & 5 & 42 & 7 & 52 & 80 \\
\hline Mineral & Opx & Opx & Opx & Opx & Opx & Opx & Cpx & Cpx & Cpx & Cpx & Cpx & $\mathrm{Cpx}$ \\
\hline $\mathrm{SiO} 2$ & 48.73 & 49.75 & 50.18 & 50.72 & 52.22 & 52.34 & 51.40 & 49.47 & 51.54 & 52.30 & 49.91 & 51.01 \\
\hline $\mathrm{TiO} 2$ & 0.28 & 0.23 & 0.13 & 0.27 & 0.54 & 0.17 & 0.44 & 0.64 & 0.11 & 0.66 & 1.17 & 0.58 \\
\hline $\mathrm{A} 12 \mathrm{O} 3$ & 6.09 & 4.19 & 1.86 & 2.40 & 5.85 & 1.43 & 2.39 & 8.33 & 1.75 & 3.33 & 4.30 & 2.65 \\
\hline $\mathrm{FeO}$ & 22.13 & 23.99 & 32.44 & 27.98 & 13.82 & 18.98 & 8.05 & 6.13 & 11.35 & 8.44 & 9.95 & 10.59 \\
\hline $\mathrm{Cr} 2 \mathrm{O} 3$ & 0.10 & 0.09 & - & 0.01 & - & - & - & 0.03 & 0.05 & 0.25 & 0.22 & 0.05 \\
\hline $\mathrm{MnO}$ & - & 0.37 & 0.70 & 0.53 & 0.26 & 0.34 & 0.14 & 0.13 & 0.20 & 0.15 & 0.27 & 0.83 \\
\hline $\mathrm{MgO}$ & 21.27 & 19.58 & 14.45 & 17.22 & 26.41 & 24.51 & 14.96 & 13.57 & 10.70 & 14.73 & 14.27 & 12.73 \\
\hline $\mathrm{CaO}$ & 0.21 & 0.57 & 0.50 & 0.89 & 0.90 & 1.05 & 21.03 & 20.20 & 24.63 & 20.15 & 18.51 & 20.64 \\
\hline $\mathrm{Na} 2 \mathrm{O}$ & - & 0.02 & 0.03 & 0.03 & 0.11 & 0.01 & 0.47 & 1.08 & 0.27 & 0.34 & 0.24 & 0.24 \\
\hline $\mathrm{K} 2 \mathrm{O}$ & 0.01 & 0.01 & - & 0.02 & - & - & - & 0.01 & - & - & - & - \\
\hline Total & 98.82 & 98.80 & 100.29 & 100.07 & 100.11 & 98.83 & 98.87 & 99.59 & 100.60 & 100.35 & 98.81 & 99.32 \\
\hline TSi & 1.828 & 1.892 & 1.962 & 1.945 & 1.866 & 1.939 & 1.919 & 1.815 & 1.940 & 1.932 & 1.881 & 1.930 \\
\hline TAl & 0.172 & 0.108 & 0.038 & 0.055 & 0.134 & 0.061 & 0.081 & 0.185 & 0.060 & 0.068 & 0.119 & 0.070 \\
\hline M1Al & 0.097 & 0.080 & 0.047 & 0.053 & 0.113 & 0.001 & 0.024 & 0.175 & 0.018 & 0.076 & 0.071 & 0.048 \\
\hline MlTi & 0.008 & 0.007 & 0.004 & 0.008 & 0.015 & 0.005 & 0.012 & 0.018 & 0.003 & 0.018 & 0.033 & 0.016 \\
\hline $\mathrm{M} 1 \mathrm{Fe} 2$ & 0.000 & 0.000 & 0.107 & 0.000 & 0.000 & 0.000 & 0.131 & 0.064 & 0.357 & 0.087 & 0.087 & 0.216 \\
\hline $\mathrm{M} 1 \mathrm{Cr}$ & 0.003 & 0.003 & 0.000 & 0.000 & 0.000 & 0.000 & 0.000 & 0.001 & 0.001 & 0.007 & 0.007 & 0.001 \\
\hline $\mathrm{M} 1 \mathrm{Mg}$ & 0.892 & 0.911 & 0.842 & 0.938 & 0.870 & 0.994 & 0.832 & 0.742 & 0.601 & 0.811 & 0.802 & 0.718 \\
\hline $\mathrm{M} 2 \mathrm{Mg}$ & 0.297 & 0.200 & 0.000 & 0.046 & 0.537 & 0.359 & 0.000 & 0.000 & 0.000 & 0.000 & 0.000 & 0.000 \\
\hline $\mathrm{M} 2 \mathrm{Fe} 2$ & 0.694 & 0.763 & 0.954 & 0.897 & 0.413 & 0.588 & 0.120 & 0.124 & 0.000 & 0.174 & 0.226 & 0.119 \\
\hline $\mathrm{M} 2 \mathrm{Mn}$ & 0.000 & 0.012 & 0.023 & 0.017 & 0.008 & 0.011 & 0.004 & 0.004 & 0.006 & 0.005 & 0.008 & 0.027 \\
\hline $\mathrm{M} 2 \mathrm{Ca}$ & 0.009 & 0.023 & 0.021 & 0.037 & 0.034 & 0.042 & 0.841 & 0.794 & 0.993 & 0.797 & 0.747 & 0.837 \\
\hline $\mathrm{M} 2 \mathrm{Na}$ & 0.000 & 0.001 & 0.002 & 0.002 & 0.008 & 0.001 & 0.034 & 0.077 & 0.020 & 0.024 & 0.018 & 0.018 \\
\hline $\mathrm{M} 2 \mathrm{~K}$ & 0.000 & 0.000 & 0.000 & 0.001 & 0.000 & 0.000 & 0.000 & 0.000 & 0.000 & 0.000 & 0.000 & 0.000 \\
\hline Cations & 4.000 & 4.000 & 4.000 & 3.999 & 4.000 & 4.000 & 4.000 & 4.000 & 4.000 & 4.000 & 4.000 & 4.000 \\
\hline wo & 0.45 & 1.22 & 1.08 & 1.89 & 1.85 & 2.09 & 43.61 & 45.94 & 50.75 & 42.55 & 39.95 & 43.67 \\
\hline EN & 62.86 & 58.17 & 43.26 & 50.86 & 75.55 & 67.88 & 43.14 & 42.94 & 30.67 & 43.28 & 42.85 & 37.46 \\
\hline FS & 36.69 & 40.61 & 55.67 & 47.26 & 22.60 & 30.03 & 13.25 & 11.12 & 18.58 & 14.16 & 17.21 & 18.87 \\
\hline
\end{tabular}

* Peraluminous orthopyroxene-bearing SCS felsic xenolith.

liths. Some clinopyroxenes show convex-upward LREE patterns with a peak at $\mathrm{Sm}$, similar to the general pattern of clinopyroxene in ultramafic xenoliths with the exception of marke negative Eu anomalies (Fig. 6). Clinopyroxene from charnockite 102131 has a flatter REE pattern and a marked positive Eu anomaly. Clinopyroxene showing negative Eu anomalies are common in mafic granulite xenoliths (Loock et al., 1990; Upton et al., 2001; Storkey et al., 2005), whereas those with positive anomalies are more unusual and have been interpreted as indicative of high oxygen fugacity during high-T metamorphism (Rogers \& Hawkesworth, 1982; Loock et al., 1990) or by metamorphic reaction with feldspar in plagioclase-rich granulites (Ulianov et al., 2006).

\section{Accessories}

Charnockite rutile has high $\mathrm{Zr}$ contents (close to $4500 \mathrm{ppm}$ ), slightly lower than in associated peraluminous granulites, where they can reach $6900 \mathrm{ppm}$ (Villaseca et $\mathbf{l}$., 2007). The high $\mathrm{Zr}$ content of charnockite rutiles is typical of granulite-facies conditions (Zack et al., 2004). Apatites have high total LREE contents (around $7300 \mathrm{ppm}$ ) and significant amounts of Sr (300 ppm) and Th (32 ppm) (Ta- ble4). They have high $\mathrm{Ce}_{N} / \mathrm{Yb}_{N}$ ratios (15) and low $\mathrm{Eu} / \mathrm{Eu}$ * values (0.13), the latter being much lower than in other mafic granulites (Loock et al., 1990; Upton et al., 2001), and typical of equilibration with the modally abundant plagioclase (Storkey et al., 2005).

\section{P-T estimates}

Equilibration pressures of the charnockite xenoliths must have been less than 10-12 kbar, otherwise garnet would have been stable. In melting experiments on tonalite rocks, garnet replaces orthopyroxene at pressures $>12 \mathrm{kbar}$ (Patiño Douce \& McCarthy, 1998) and garnet also appears at $10 \mathrm{kbar}$ in most meta-gabbro melting experiments (e.g. Springer \& Seck, 1997). P-T estimates were obtained using the PTMAFIC program of Soto \& Soto (1995). Pressures of between 9 to $12 \mathrm{kbar}$ were obtained using $\mathrm{cpx}+$ plag + qtz equilibria (Ellis, 1980) in those charnockites with two pyroxenes or only clinopyroxene (Table 5). Pressure estimates based on garnet-orthopyroxene equilibria (Newton \& Perkins, 1982; Brey et al., 1986) for associate peraluminous granulite xenoliths gave similar values mostly in the range of 9 to $11 \mathrm{kbar}$ (Table 5). Moreover, SCS pyrox- 

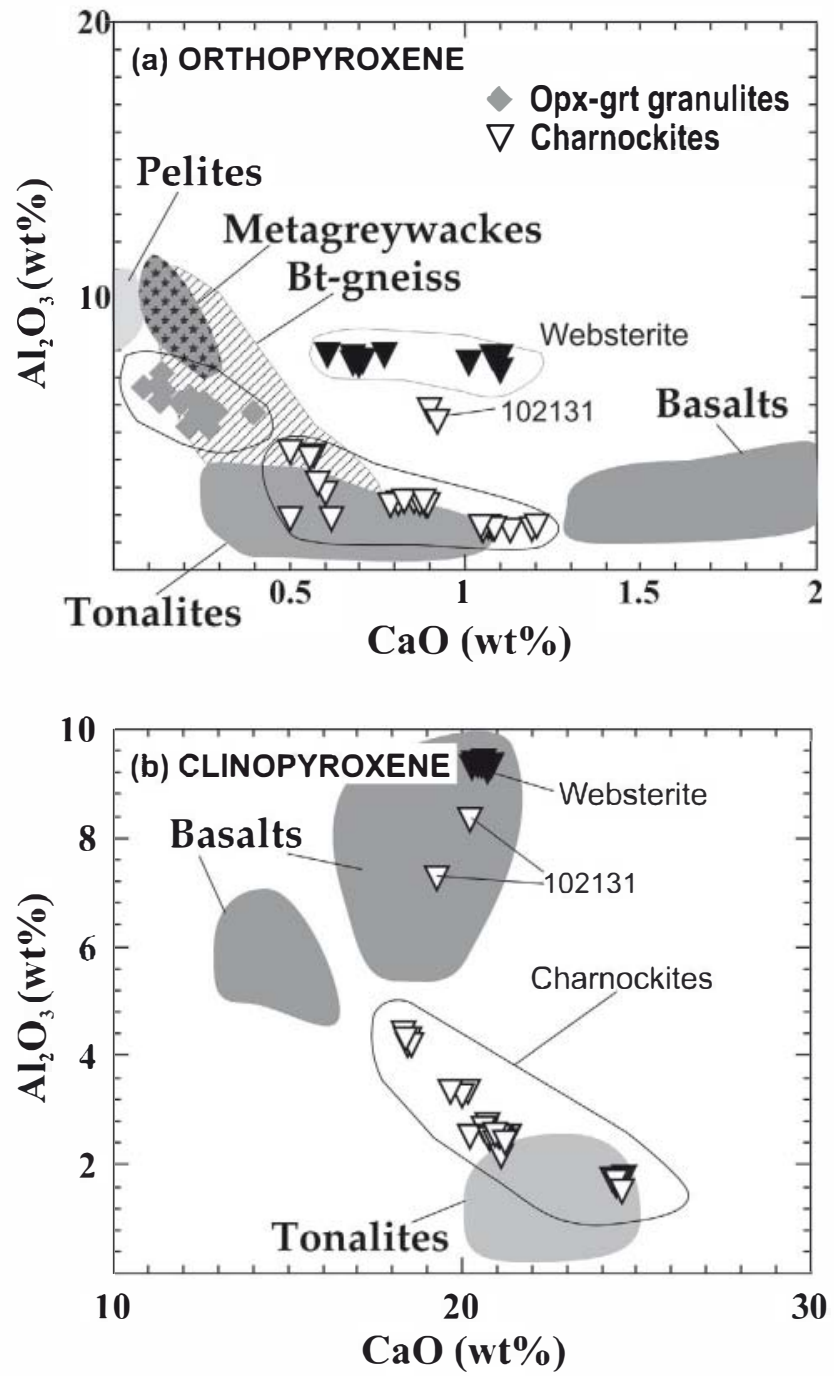

Fig. 5. $\mathrm{Ca} v$ vs. $\mathrm{Al}_{2} \bullet_{3}$ (wt.\%) in pyroxene from various SCS granulite xenoliths: a) orthopyroxene, b) clinopyroxene. Websterite pyroxene compositional field is taken from Orejana et al. (2006). Pyroxene from SCS granulite xenoliths are compared to compositional fields of restitic pyroxenes in melting experiments (at conditions of vapor-absent and $\mathrm{P}$ of 5 to $12 \mathrm{kbar}$ ). Fields are average pyroxene composition from partial fusion experiments of pelites (Carrington \& Harley, 1995), aluminous metagreywackes (Montel \& Vielzeuf, 1997), biotite gneisses (Patiño Douce \& Beard, 1995), tonalites (Singh \& Johannes, 1996), and basalts (meta-gabbro 87S35A from Sisson et al. 2005; metabasites from Springer \& Seck, 1997).

enite xenoliths yielded the same pressure range for recrystallization (Orejana et al., 2006).

Temperatures estimates in charnockites have been determined using two-pyroxene or Ca-in-orthopyroxene geothermometers (Wells, 1977; Wood \& Banno, 1973; Brey \& Köller, 1990). A range of 915 to $1060^{\circ} \mathrm{C}$ has been obtained (Table 5). The garnet-orthopyroxene geothermometer of Harley (1984) and Al-in-orthopyroxene equilibria of Witt-Eickschen \& Seck (1991) give similar values of 870 to $990{ }^{\circ} \mathrm{C}$ for the more felsic peraluminous orthopyroxene-garnet granulites. Moreover, the occurrence
Table 4. Average mineral trace element (LA-ICPMS) composition (in ppm).

\begin{tabular}{|c|c|c|c|c|c|c|c|c|c|}
\hline Mineral & PI & PI & Opx & Opx & Opx & Cpx & Cpx & Rt & Ap \\
\hline Sample & 105775 & $\mathrm{U}-28$ & U-28 & 102131 & $105796 *$ & 102131 & 105775 & U-28 & $\mathrm{U}-28$ \\
\hline $\mathrm{n}$ & 3 & 3 & 3 & 2 & 3 & 1 & 4 & 2 & 2 \\
\hline$\overline{\mathrm{Li}}$ & 24.83 & 1.78 & & & & & & & 2.21 \\
\hline $\mathrm{P}$ & 177 & 142 & & & & & & 114 & 133900 \\
\hline $\mathrm{Sc}$ & 3.04 & 2.58 & 43.37 & & 24.94 & & 115 & 29.33 & 2.62 \\
\hline V & 3.20 & 1.06 & 293 & 292 & 772 & 182 & 527 & 2285 & 4.34 \\
\hline $\mathrm{Cr}$ & 17.09 & 11.74 & 986 & 98.29 & 377 & 69.39 & 1336 & 4824 & 9.29 \\
\hline $\mathrm{Rb}$ & 120 & 4.25 & & & & 0.56 & & & \\
\hline $\mathrm{Sr}$ & 451 & 498 & 0.43 & & & 51.65 & 19.03 & & 303 \\
\hline $\mathrm{Ba}$ & 304 & 270 & & & & & & & 7.69 \\
\hline $\mathrm{Zr}$ & & & 5.40 & 7.32 & 13.87 & 6.69 & 65.78 & 4433 & 4.27 \\
\hline $\mathrm{Nb}$ & & & & & & 1.06 & & 1255 & \\
\hline $\mathrm{Ta}$ & & & & & & 0.06 & & 51.61 & \\
\hline Hf & & & 0.25 & 0. 46 & 0.91 & 0.29 & 2.77 & 103 & 0.12 \\
\hline $\mathrm{Pb}$ & 1.05 & 14.40 & 0.16 & & & & - .24 & 0.40 & 5.17 \\
\hline Th & & & & & & 0. 72 & 0.20 & & 31.92 \\
\hline $\mathrm{U}$ & & & & & & & & 7.40 & 4.82 \\
\hline Y & 0.54 & $\bullet .56$ & 12.42 & 2.20 & 3.19 & 3.27 & 47.97 & 1.01 & 1035 \\
\hline $\mathrm{La}$ & 2.00 & 14.99 & & & & 1.84 & 3.09 & & 1279 \\
\hline $\mathrm{Ce}$ & 4.53 & 23.84 & 0.29 & 0.05 & - .31 & 5.47 & 11.68 & & 3263 \\
\hline $\operatorname{Pr}$ & 0.52 & 2.12 & & & 0.10 & 0.73 & 2.61 & & 434 \\
\hline Nd & 2.17 & 6.40 & 0.82 & & 1.09 & 2.52 & 17.92 & & 1970 \\
\hline $\mathrm{Sm}$ & 0.55 & 0.74 & 0.63 & & 1.00 & 1.14 & 8.12 & & 403 \\
\hline $\mathrm{Eu}$ & 1.00 & 1.93 & & & & 1.08 & 0.51 & & 14.35 \\
\hline Gd & & & 0.65 & & 1.24 & - .77 & 8.98 & & 321 \\
\hline $\mathrm{Tb}$ & & & 0.22 & 0.10 & 0.17 & 0.13 & 1.57 & & 42.76 \\
\hline Dy & & •. 29 & 1.83 & 0.31 & - .91 & 0.63 & 9.76 & & 216.4 \\
\hline Ho & & & 0.49 & 0.11 & 0.17 & 0.17 & 1.99 & & 39.48 \\
\hline $\mathrm{Er}$ & & & 1.63 & 0.35 & 0.49 & 0.53 & 5.05 & & 89.94 \\
\hline $\mathrm{Tm}$ & & 0.05 & 0.34 & 0.07 & & 0.10 & •.69 & & 10.30 \\
\hline $\mathrm{Yb}$ & & & 2.68 & ๑. 39 & & 0.43 & 4.26 & & 56.04 \\
\hline $\mathrm{Lu}$ & & & 0.51 & 0.10 & & 0.13 & 0.60 & & 6.90 \\
\hline
\end{tabular}

Blank rows mean below detection limits by LA-ICPMS

* Peraluminous orthopyroxene-garnet-bearing xenolith.

of orthopyroxene in peraluminous granulites with high-TiF mica and a Ti-bearing phase (rutile/ilmenite) has been observed experimentally in the range 925 to $1050{ }^{\circ} \mathrm{C}$ for the estimated pressure conditions (Nair \& Chacko, 2002).

Estimated temperatures in SCS pyroxene-bearing xenoliths are slightly higher than those for the felsic granulite xenoliths, a situation that occurs in other xenolith suites; pyroxene thermometry tends to overestimate temperature (e.g. Al-Mishwat and Nasir, 2004). Similarly, the application of $\mathrm{Zr}$-in-rutile geothermometry yields a varied range of T estimates, depending of the calibration used. The empirical version of Zack et al. (2004) gives 960 to $1060^{\circ} \mathrm{C}$, whilst the experimental approach of Watson et al. (2006) yields a range of 830 to $930^{\circ} \mathrm{C}$ (Table 5).

These results overlap with the estimated granulitic $P$ $T$ conditions in the SCS felsic and pelitic xenolith suites (Villaseca et al., 1999), although $P-T$ estimates in the charnockites are higher. Nevertheless, estimated equilibration pressures, mostly in the range of 9 to $11 \mathrm{kbar}$, suggest that all quartz-feldspathic xenoliths could be derived from lower crustal levels. In addition, these $P-T$ estimates are in agreement with the lack of garnet in basic granulites and the general presence of sillimanite (instead of kyanite) in associated peraluminous granulite xenoliths. 


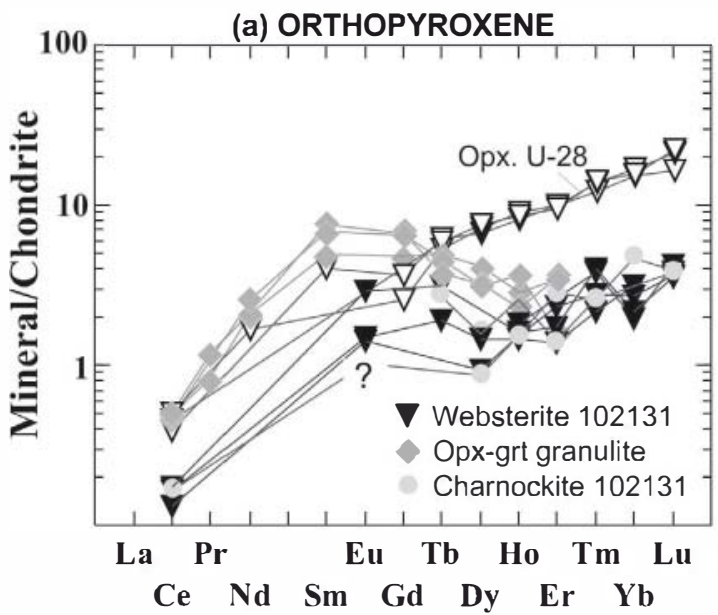

(b) CLINOPYROXENE

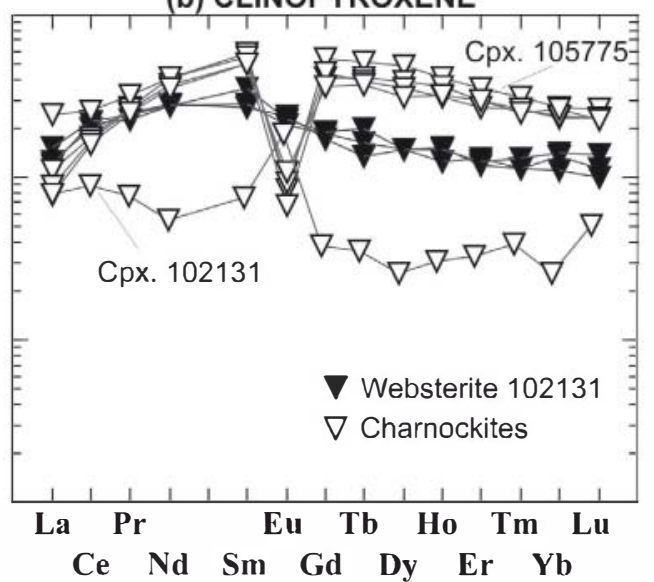

Fig. 6. Chondrite-normalised REE patterns for pyroxenes from SCS granulite xenoliths: a) orthopyroxene, b) clinopyroxene. Normalising values are from Sun \& McDonough (1989). Pyroxene websterite data (inverted full triangle) are from Orejana et al. (2006). Orthopyroxene from charnockite 102131 (full circle) plot above websterite data.

Table 5. $P-T$ determinations on SCS pyroxene-bearing xenoliths.

\begin{tabular}{|c|c|c|c|c|c|c|c|c|}
\hline & Xenolith type & $T(1)$ & $T(2)$ & $T(3)$ & $T(4)$ & $T(5)$ & $T(6)$ & $P(1) P(2) P(3)$ \\
\hline 102131 & Charnock. 2 pyrox. & 1017 & 988 & & 1006 & & & \\
\hline $\mathrm{U}-28$ & " & 935 & 958 & & 1062 & 918 & 988 & 12 \\
\hline 104551 & Charnock. Cpx & & & & & 930 & 1060 & $9-12.7$ \\
\hline 105775 & ". & & & & & 827 & 960 & 10 \\
\hline 104867 & Charnock. Opx & & & & 943 & & & \\
\hline $103490 \mathbf{B}$ & $"$ & & & & 916 & & & \\
\hline $\mathrm{U}-3$ & " & & & & 1023 & & & \\
\hline 105796 & (Opx-Grt) Felsic & & & 950 & 973 & 740 & 850 & 12.711 \\
\hline 81846 & ". & & & 870 & 992 & & & 9.2 \\
\hline 81845 & . & & & 910 & 894 & & & 11.09 .4 \\
\hline
\end{tabular}

$T$ in ${ }^{\circ} \mathrm{C}$ and $P$ in kbar. $T(1)$ Wood \& Banno (1973); $T$ (2) Wells (1984); $T$ (3) Harley (1984); $T(4)$ Brey \& Koler (1990) for charnockites, and Witt-Eickschen \& Seck (1991) for orthopyroxene-bearing felsic granulites; $T$ (5) Watson et al. (2006); $T(6)$ Zack et al. (2004); P(1) Ellis (1980); P(2) Newton \& Perkins (1982); P(3) Brey et al. (1986).

\section{Whole-rock geochemistry}

\section{Major elements}

Major and race element data for 7 whole-rock samples (4 charnockites and 3 orthopyroxene-garnet granulites) are given in Table 6.

Although charnockites are aluminium-rich (with 14 to 19 wt. $\% \mathrm{Al}_{2} \mathrm{O}_{3}$ ) they are always metaluminous in composition, in contrast with orthopyroxene-garnet granulites which are moderately to highly peraluminous (A/CNK values from 1.2 to 1.7). According to their $\mathrm{SiO}_{2}$ content, charnockites range from basic to mainly intermediate composition whereas orthopyroxene-garnet granulites are more silica-rich (intermediate to acid) (Table 6). Charnockites show lower $\mathrm{Al}_{2} \mathrm{O}_{3}, \mathrm{FeO}, \mathrm{TiO}_{2}, \mathrm{~K}_{2} \mathrm{O}$ and higher $\mathrm{CaO}$ contents than felsic and pelitic xenoliths (Fig. 7). Nevertheless, they show a high $\mathrm{K}_{2} \mathrm{O}$ content, mainly from 1.65 to $3.38 \mathrm{wt}$ \%, plotting mostly in high- $\mathrm{K}$ fields on the basis of their concentrations of $\mathrm{K}_{2} \mathrm{O}$ and $\mathrm{SiO}_{2}$ (Le Maitre et al., 1989). $\mathrm{MgO}$ and $\mathrm{Na}_{2} \mathrm{O}$ contents are intermediate between those of felsic and pelitic xenoliths (Fig. 7), except for two charnockites, which show very high $\mathrm{Na}_{2} \mathrm{O}$ contents. The most basic charnockite (105775) has the lowest $\mathrm{Na}_{2} \mathrm{O}$ content (1.49 wt.\%) but also the highest $\mathrm{CaO}$ content (10.4 wt.\%) (Table 6).

Most of the analyzed charnockites are hypersthene normative but have some olivine in the CIPW norm (2.8 to 8.7 wt.\%), although xenolith U-3 has 15.8 wt.\% normative quartz (Table 6). All have normative orthoclase (822 wt.\%).

\section{Trace elements}

Charnockites show lower contents of REE-Y and HFSE (Th-U-Zr-Nb-Ta) than peraluminous granulite xenoliths, except the most felsic sample 105779. Moreover, they show slightly lower $\mathrm{Rb}-(\mathrm{Ba})-\mathrm{Cs}$ contents, but similar Sr. More remarkable is their slightly lower $\mathrm{Ni}-(\mathrm{Cr})-\mathrm{V}$ contents than felsic or pelitic xenoliths (Fig. 7).

According to REE and multi-element patterns the most basic charnockite $\mathbf{1 0 5 7 7 5}$ is markedly different to the rest (Fig. 8a,b). It has the lowest trace-element contents and the flattest REE pattern, similar to those of some associated pyroxenite xenoliths. In fact, it has nearly the same multielement pattern as websterite xenolith 102131 of Orejana et al. (2006), but has higher LILE contents (Rb, K, Sr, Ba). The other charnockites show a fractionated LREE pattern and a variably negative Eu anomaly, similar to those of the felsic granulite xenoliths, although with lower HREE contents (Fig. 8a). In normalised multi-element plots they show negative Th-U, Nb-Ta and Ti anomalies, and positive $\mathrm{Pb}$ and $\mathrm{P}$ anomalies. The lack of coherent element correlations suggests that the charnockite samples should not be treated as a single cogenetic group.

\section{$\mathrm{Sr}-\mathrm{Nd}-\mathrm{Pb}$ isotopes}

Measured $\mathrm{Sr}, \mathrm{Nd}$ and $\mathrm{Pb}$ isotopic ratios for these xenoliths are given in Table 7. Their Sr-Nd isotope compositions 
Table 6. Major (wt.\%) and trace element (ppm) composition of the SCS pyroxene-bearing xenoliths.

\begin{tabular}{|c|c|c|c|c|c|c|c|}
\hline Sample & 105775 & 103490-B & 105779 & U-3 & 103184 & 81845 & 105796 \\
\hline & Charnockite & Charnockite & Charnockite & Charnockite & Opx-grt-granulite & Opx-grt-granulite & Opx-grt-granulite \\
\hline $\mathrm{SiO} 2$ & 46.68 & 52.37 & 52.77 & 59.94 & 48.26 & 59.36 & 71.03 \\
\hline $\mathrm{TiO} 2$ & 0.78 & 1.26 & 0.49 & 0.60 & 1.66 & 1.12 & 0.60 \\
\hline $\mathrm{Al} 2 \mathrm{O} 3$ & 18.08 & 19.32 & 18.98 & 13.98 & 19.55 & 17.29 & 13.75 \\
\hline $\mathrm{Fe} 2 \mathrm{O} 3$ & 8.32 & 7.51 & 5.28 & 4.14 & 14.85 & 7.13 & 4.28 \\
\hline $\mathrm{MnO}$ & 0.11 & 0.13 & 0.16 & 0.07 & 0.19 & 0.07 & 0.06 \\
\hline $\mathrm{MgO}$ & 7.41 & 4.21 & 3.16 & 1.71 & 6.13 & 3.19 & 2.17 \\
\hline $\mathrm{CaO}$ & 10.4 & 5.75 & 6.15 & 6.22 & 3.39 & 2.28 & 1.57 \\
\hline $\mathrm{Na} 2 \mathrm{O}$ & 1.49 & 4.61 & 5.26 & 3.17 & 2.49 & 3.15 & 3.37 \\
\hline $\mathrm{K} 2 \mathrm{O}$ & 1.65 & 1.38 & 2.59 & 3.38 & 0.93 & 3.89 & 1.62 \\
\hline $\mathrm{P} 2 \mathrm{O} 5$ & 0.05 & 0.38 & 0.27 & 0.32 & 0.07 & 0.19 & 0.09 \\
\hline LOI & 4.92 & 2.46 & 5.25 & 6.05 & 1.26 & 2.00 & 1.35 \\
\hline Total & 99.89 & 99.38 & 100.36 & 99.58 & 98.79 & 99.67 & 99.89 \\
\hline $\mathrm{ACNK}^{*}$ & 0.78 & 0.99 & 0.84 & 0.69 & 1.74 & 1.28 & 1.35 \\
\hline $\mathbf{B a}$ & 312 & 32 & 2846 & 794 & 547 & 1050 & 703 \\
\hline $\mathrm{Rb}$ & 119 & 46.1 & 99.6 & 119 & 13 & 121 & 50.1 \\
\hline $\mathrm{Sr}$ & 257 & 409 & 1670 & 415 & 369 & 347 & 453 \\
\hline $\mathrm{Pb}$ & 0.50 & 7.59 & 8.50 & 6.00 & 14.00 & 21.00 & 12.50 \\
\hline Th & 0.10 & 2.92 & 7.16 & 0.24 & 5.27 & 37.90 & 2.38 \\
\hline $\mathrm{U}$ & 0.03 & 0.88 & 3.56 & 0.25 & 1.05 & 1.43 & 0.38 \\
\hline $\mathrm{Zr}$ & 34.5 & 367 & 146 & 121 & 137 & 263 & 157 \\
\hline $\mathrm{Nb}$ & 2.11 & 11.80 & 8.84 & 6.00 & 13.60 & 7.70 & 3.47 \\
\hline $\mathrm{Y}$ & 17.60 & 19.40 & 28.60 & 20.70 & 72.30 & 21.90 & 26.20 \\
\hline $\mathrm{Sc}$ & n.d. & n.d. & n.d. & 11 & 37 & 17 & n.d. \\
\hline $\mathrm{V}$ & 203 & 147 & 139 & 56 & 270 & 162 & 59 \\
\hline Co & 32 & 25 & 27 & 8 & 27 & 21 & 9 \\
\hline $\mathrm{Cr}$ & 636 & 161 & 102 & 16 & 172 & 100 & 69 \\
\hline $\mathrm{Ni}$ & 50 & 58 & 86 & 15 & 37 & 47 & 19 \\
\hline $\mathrm{Ga}$ & 17.40 & 24.20 & 24.40 & 16.00 & 24.00 & 22.00 & 14.80 \\
\hline $\mathrm{Ta}$ & 0.11 & 0.67 & 1.41 & 0.32 & 0.62 & 0.50 & 0.20 \\
\hline $\mathrm{Hf}$ & 1.26 & 8.40 & 4.47 & 3.20 & 3.90 & 7.20 & 3.98 \\
\hline $\mathrm{Cs}$ & 4.81 & 3.37 & 0.59 & 3.00 & 4.70 & 7.70 & 2.70 \\
\hline $\mathrm{La}$ & 3.35 & 22.10 & 33.40 & 19.70 & 35.70 & 62.60 & 37.60 \\
\hline $\mathrm{Ce}$ & 7.89 & 48.30 & 64.30 & 43.00 & 67.10 & 127.00 & 62.80 \\
\hline Pr & 1.34 & 6.17 & 8.04 & 5.30 & 7.60 & 15.00 & 6.71 \\
\hline $\mathrm{Nd}$ & 7.45 & 25.70 & 32.70 & 22.10 & 29.30 & 56.00 & 24.20 \\
\hline $\mathrm{Sm}$ & 2.74 & 5.27 & 6.95 & 5.09 & 7.20 & 8.34 & 4.13 \\
\hline $\mathrm{Eu}$ & 0.78 & 1.62 & 1.23 & 1.39 & 2.62 & 2.46 & 2.11 \\
\hline $\mathrm{Gd}$ & 3.13 & 4.57 & 6.02 & 5.31 & 9.95 & 5.31 & 4.22 \\
\hline $\mathrm{Tb}$ & 0.53 & 0.65 & 0.94 & 0.87 & 2.00 & 0.76 & 0.72 \\
\hline Dy & 3.19 & 3.57 & 5.31 & 4.44 & 12.80 & 4.11 & 4.49 \\
\hline Ho & 0.64 & 0.69 & 1.02 & 0.81 & 2.74 & 0.84 & 0.91 \\
\hline $\mathrm{Er}$ & 1.72 & 1.84 & 2.81 & 2.33 & 8.70 & 2.75 & 2.60 \\
\hline $\mathrm{Tm}$ & 0.24 & 0.28 & 0.40 & 0.31 & 1.28 & 0.41 & 0.40 \\
\hline $\mathrm{Yb}$ & 1.56 & 1.77 & 2.72 & 1.75 & 8.02 & 2.63 & 2.67 \\
\hline $\mathrm{Lu}$ & 0.23 & 0.30 & 0.41 & 0.24 & 1.15 & 0.39 & 0.42 \\
\hline \multicolumn{8}{|c|}{$C I P W$ n॰rn } \\
\hline$Q-$ & - & - & - & 15.78 & 6.44 & 13.93 & 37.41 \\
\hline Or & 10.36 & 8.48 & 16.19 & 21.46 & 5.72 & 23.71 & 9.76 \\
\hline$A b$ & 13.36 & 40.48 & 39.83 & 28.76 & 21.87 & 27.44 & 29.02 \\
\hline$A n$ & 40.02 & 27.34 & 21.65 & 14.91 & 17.06 & 10.51 & 7.46 \\
\hline$C$ & - & 0.61 & - & - & 8.75 & 4.27 & 3.85 \\
\hline$D i$ & 11.71 & - & 7.33 & 13.44 & - & - & - \\
\hline Hy & 12.48 & 15.40 & - & 2.81 & 33.67 & 16.08 & 10.34 \\
\hline Ol & 8.65 & 2.81 & 8.43 & - & - & - & - \\
\hline $\mathrm{Ne}$ & - & - & 3.87 & - & - & - & - \\
\hline$M t$ & 1.74 & 1.54 & 1.10 & 0.87 & 3.05 & 1.45 & 0.85 \\
\hline$I l m$ & 1.57 & 2.40 & 0.98 & 1.23 & 3.29 & 2.19 & 1.16 \\
\hline$A p$ & 0.12 & 0.86 & 0.62 & 0.75 & 0.16 & 0.43 & 0.20 \\
\hline
\end{tabular}

n.d.: not determined. *ACNK $=\operatorname{molar}\left(\mathrm{Al}_{2} \mathrm{O}_{3} /\left(\mathrm{CaO}+\mathrm{Na}_{2} \mathrm{O}+\mathrm{K}_{2} \mathrm{O}\right)\right)$. 

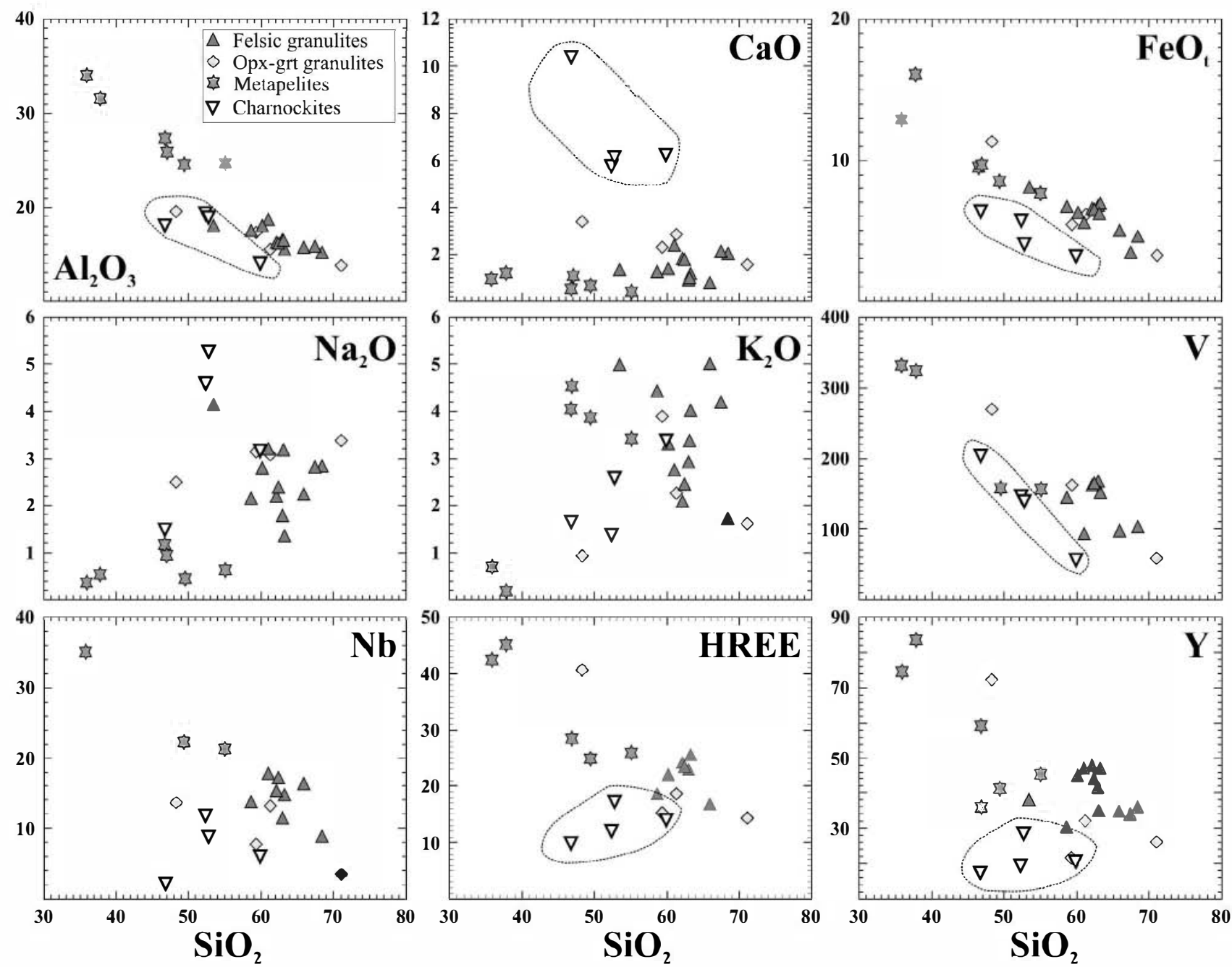

Fig. 7. Major (wt.\%) and trace (ppm) elements vs. $\mathrm{Si}_{2}$ variation diagrams for SCS granulite xenoliths. Felsic and metapelitic xenoliths are taken from Villaseca et al. (1999).

are plotted in Fig. 9 together with isotopic values from the other granulite xenolith suites (Villaseca et al., 1999) and from calc-alkaline pyroxenite xenoliths (Orejana et al., 2006). Initial isotopic ratios have been calculated at 300 $\mathrm{Ma}$, which is the average age for granulite recrystallization of the lower crustal xenoliths (Fernández Suárez et al., 2006). In the age-corrected $\varepsilon_{\mathrm{N}} v s .{ }^{87} \mathrm{Sr} /{ }^{86} \mathrm{Sr}$ diagram (Fig. 9), charnockites plot towards BSE values, and display a slightly lower Sr-Nd isotopic composition than associated peraluminous granulite xenoliths. Nevertheless, two of the most acid charnockites (U-3 and 103490B) plot inside the felsic granulite field. More basic charnockites have similar $\mathrm{Sr}$ and $\mathrm{Nd}$ isotope values to those pyroxenite xenoliths. The $\mathrm{Pb}$ isotope data confirms the similarity between the most basic charnockite 105775 and the calc-alkaline pyroxenite xenoliths, which yields the highest ${ }^{206} \mathrm{~Pb} /{ }^{204} \mathrm{~Pb}$ ratio (Fig. 10). Again, charnockite $103490 \mathrm{~B}$ plots within the same $\mathrm{Pb}$ isotope compositional field as the other SCS granulite xenoliths (defined by felsic meta-igneous granulites, Table 7), although toward lower ${ }^{208} \mathrm{~Pb} /{ }^{204} \mathrm{~Pb}$ values (Fig. 10b).
The different SCS xenolith types show a restricted range in $\mathrm{Pb}$ isotope composition, similar to that defined by other European lower crustal xenoliths (Downes, 1993). The limited variation in initial $\mathrm{Pb}$ isotopic composition of SCS lower crustal xenoliths (charnockite, felsic and pelitic granulites) contrasts with their wide variation in $\varepsilon_{\mathrm{Nd}}$ and ${ }^{87} \mathrm{Sr} /{ }^{86} \mathrm{Sr}$ values.

\section{Discussion}

Nature of granulitic proteliths: restites or cumulates from previous magma underplating events?

Very scarce basic rocks are present in the SCS. Outcropping metamorphic rocks of Neoproterozoic to Lower Palaeozoic age are characterized by rare occurrences of meta-basites; minor continental-type tholeiitic metabasites were described by Barbero \& Villaseca (2000). The lack of basic magmatic input associated with the Hercynian collision is remarkable, estimated to be much less than 

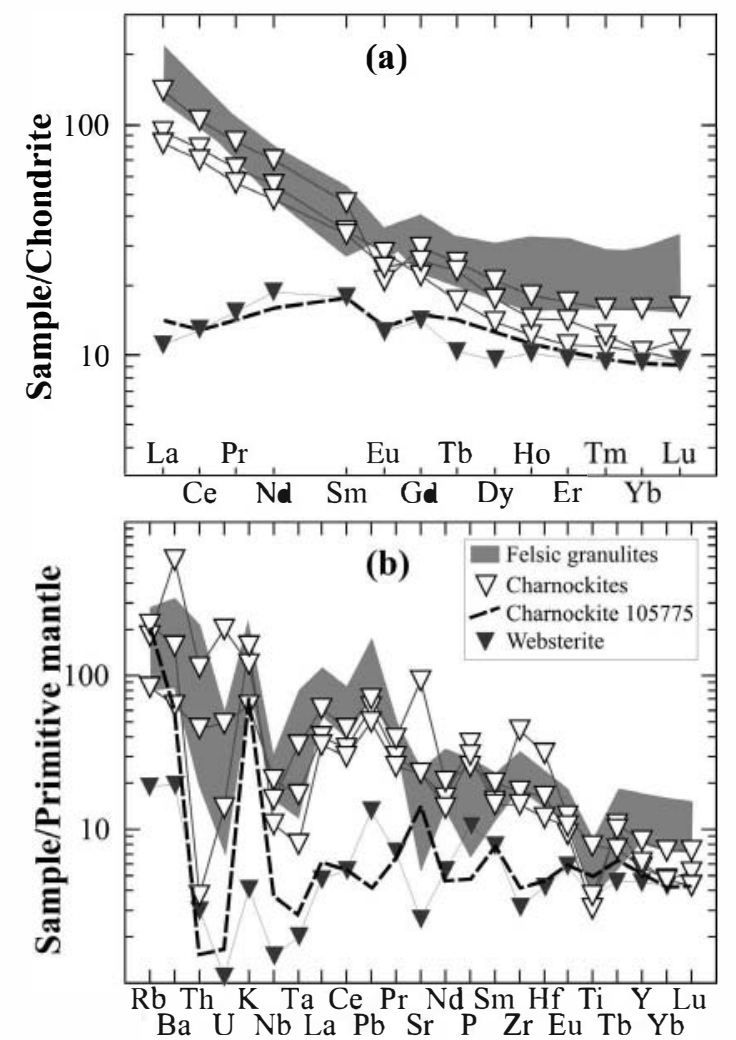

Fig. 8. Trace element diagrams for SCS granulite xenoliths: a) REE compositions normalised to chondrite values of Sun \& McDonough (1989), b) incompatible trace element compositions normalised to primitive mantle values of McDonough \& Sun (1995). Felsic granulite data from Villaseca et al. (1999), websterite data from Orejana et al. (2006).

1 vol.\% of the total Hercynian SCS batholith (Villaseca et al., 1998; Bea et al., 1999; Villaseca \& Herreros, 2000). The origin and nature of the protoliths of the basic to intermediate granulite xenoliths described in this work is relevant to clarify the composition and evolution of this complex orogenic continental sector.

The varied chemical composition of the charnockites suggests multiple origins. For example, the isotopic data point to different charnockite protoliths which cannot be related to a single petrogenetic process (e.g. a single layered igneous complex or a unique magmatic system, even involving assimilation of lower crustal rocks). Thus, the studied SCS charnockites reflect sampling of different granulite protoliths.

Some charnockite xenoliths could be recrystallized cumulates from previous Hercynian calc-alkaline magmatic events, subsequently fragmented at the base of the crust and included by the ascending Permian alkaline lamprophyres. This is based on the lack of hydrous minerals (amphibole or mica) and chemical similarities with the calc-alkaline ultramafic xenoliths. The clinopyroxene composition of charnockite 102131 is very similar to that of clinopyroxenes in the related websterite xenolith (Orejana et al., 2006) (Fig. 5b and 6b). Charnockite orthopyroxene trace element contents are also within the same range shown by the accompanying websterite xenolith (Fig. 6a). Moreover, charnockite 105775 has a trace element whole-rock composition typical of a clinopyroxene-plagioclase cumulate, which resembles some pyroxenite xenoliths (Fig. 8). This charnockite also has the most Ca-rich plagioclase and its clinopyroxene displays a convex-upward chondritenormalized REE pattern typical of clinopyroxene formed as deep cumulate crystals from basic magmas (Irving \& Frey, 1984). Consequently, some charnockites may form part of a complex mafic-ultramafic sequence subsequently granulitize at the base of the crust after a magmatic underplating event. Their high- $\mathrm{K}$ content and Hy-normative character suggest a calc-alkaline affinity. In fact, their SrNd isotopic composition plot within the range displayed by minor Hercynian calc-alkaline basic magmas, which outcrop as small scattere gabbroic bodies in the SCS (Bea et al., 1999).

In contrast to the cumulate xenoliths discussed above, the lack of Ca-rich plagioclase and exsolution textures in pyroxenes, combined with a trace-element geochemistry that is not appropriate for plagioclase- or pyroxenedominated cumulates (Berger et al., 2005), suggest that most SCS charnockites are restitic rocks. The composition of restitic pyroxenes in melting experiments of various rocks (metapelites, metagreywackes, biotite-gneisses, basalts and tonalites) are shown in Fig. 5 and may furnish information on the charnockite protoliths. Thus, orthopyroxene formed by biotite breakdown (e.g. metapelites, gneisses) has higher $\mathrm{Al}_{2} \mathrm{O}_{3}$ contents than that orthopyroxene formed by hornblende breakdown in metaluminous protoliths (e.g. tonalites, basalts) (Fig. 5a). In a diagram of $\mathrm{Al}_{2} \mathrm{O}_{3} v s$. $\mathrm{CaO}$ composition, orthopyroxene from metapelitic rocks plots towards the highest $\mathrm{Al}_{2} \mathrm{O}_{3}$ (and lowest $\mathrm{CaO}$ ) contents; whereas those from meta-basalts have the highest $\mathrm{CaO}$ (and lowest $\mathrm{Al}_{2} \mathrm{O}_{3}$ ) contents. Charnockitic orthopyroxenes plot in an intermediate compositional field, which is closer to basic-intermediate (and metaluminous) protoliths, whereas garnet-bearing felsic granulites have orthopyroxenes of clear peraluminous felsic derivation (Alrich graywackes or biotite-bearing gneisses) (Fig. 5a). Restitic orthopyroxene from dehydration-melting experiments in metaluminous tonalites (Singh \& Johannes, 1996) match closely with the compositional field of charnockitic orthopyroxene.

Charnockite clinopyroxenes also plot in an intermediate field between restitic clinopyroxenes in melting experiments involving meta-tonalites (Singh \& Johannes, 1996) and K-rich meta-basaltic andesites (not included in Fig. 5, sample YOS-55A from Sisson et al., 2005). Restitic clinopyroxenes from more meta-basic protoliths (basalts or amphibolites) usually have higher $\mathrm{Al}_{2} \mathrm{O}_{3}$ contents (Springer \& Seck, 1997; Sisson et al., 2005) (Fig. 5b).

The absence of amphibole in metaluminous granulites is remarkable. Some dehydration melting experiments show that amphibole breakdown occurs below 900 to $950{ }^{\circ} \mathrm{C}$ (Beard \& Lofgren, 1991; Patiño Douce \& Beard, 1995; Skjerle \& Johnston, 1996), suggesting that amphibole might be a stable restite phase during dehydration melting in the lower continental crust. Moreover, other melting ex- 
Table 7. Sr, $\mathrm{Nd}$ and $\mathrm{Pb}$ isotope data for the SCS xenoliths.

\begin{tabular}{|c|c|c|c|c|c|c|c|c|c|c|c|c|c|}
\hline Sample & 105775 & 103490B & 105779 & U-3 & 103184 & 105796 & 95141* & 95148* & 77750* & $\mathrm{U} 4 \mathbf{2}^{*}$ & U-90* & 102131 ** & $104395 * *$ \\
\hline Xenolith-type & Charnock. & Charnock. & Charnock. & Charnock. & Opx-grt-granulite & Opx-grt-granulite & Felsic & Felsic & Metapelite & Metapelite & Metapelite & Websterite & Pyroxenite \\
\hline $\mathrm{Rb}(\mathrm{ppm})$ & 119 & 46.1 & 99.64 & 119 & 13 & 50.15 & 97 & 85 & 108 & 148 & 126 & 10.5 & 7.6 \\
\hline $\mathrm{Sr}(\mathrm{ppm})$ & 257.2 & 409 & 1670 & 415 & 369 & 453 & 186 & 240 & 141 & 151 & 233 & 47.2 & 60.7 \\
\hline$\left({ }^{37} \mathrm{Rb} /{ }^{26} \mathrm{Sr}\right)$ & 1.34 & 0.33 & 0.17 & 0.83 & 0.10 & 0.32 & 1.51 & 1.03 & 2.22 & 2.84 & 1.57 & 0.64 & 0.36 \\
\hline$\left({ }^{(77} \mathrm{Sr} /{ }^{66} \mathrm{Sr}\right)_{300}$ & 0.70462 & 0.70658 & 0.70508 & 0.70597 & 0.71113 & 0.70661 & 0.71051 & 0.71207 & 0.71746 & 0.70951 & 0.71359 & 0.7048 & 0.70545 \\
\hline Sm (ppm) & 2.73 & 5.27 & 6.95 & 5.09 & 7.20 & 4.13 & 6.25 & 8.13 & 11.80 & 9.45 & 6.97 & 2.7 & 3.4 \\
\hline Nd (ppm) & 7.45 & 25.70 & 32.71 & 22.10 & 29.30 & 24.18 & 27.10 & 37.60 & 64.00 & 46.00 & 20.10 & 8.70 & 10.80 \\
\hline$\left({ }^{147} \mathrm{Sm} /{ }^{144} \mathrm{Nd}\right)$ & 0.2215 & 0.1240 & 0.1284 & 0.1392 & 0.1485 & 0.1033 & 0.1396 & 0.1307 & 0.1120 & 0.1240 & 0.2101 & 0.1877 & 0.1886 \\
\hline$\left({ }^{143} \mathrm{Nd} /{ }^{144} \mathrm{Nd}\right) \mathrm{m}$ & $0.512641 \pm 05$ & $0.512362 \pm 0$ & $0.512285 \pm 06$ & $0.5123903 \pm 04$ & $0.512254 \pm 03$ & $0.512216 \pm 05$ & $0.512379 \pm 08$ & $0.512217 \pm 07$ & $0.511878 \pm 03$ & $30.511897 \pm 03$ & $0.512128 \pm 07$ & $70.512450 \pm 03$ & $0.512482 \pm 03$ \\
\hline$\left({ }^{143} \mathrm{Nd} / /^{144} \mathrm{Nd}\right)_{300}$ & 0.512205 & 0.512119 & 0.512033 & 0.512117 & 0.511958 & 0.512013 & 0.512099 & 0.511960 & 0.511659 & 0.511653 & 0.511716 & 0.512081 & 0.512112 \\
\hline $\mathrm{E}(\mathrm{Nd})_{300}$ & -0.89 & -2.60 & -4.27 & -2.63 & -5.73 & -4.66 & -2.98 & -5.69 & -11.57 & -11.6 & -10.45 & -3.33 & -2.74 \\
\hline U (ppm) & 0.03 & 0.88 & & & & 0.38 & 0.39 & 0.83 & & & & 0.0 & 0.07 \\
\hline $\mathrm{Pb}(\mathrm{ppm})$ & 0.5 & 7.59 & & & & 12.5 & 14 & 11 & Kfs. & Kfs. & $K f s$. & 1.57 & 2.59 \\
\hline$\left({ }^{206} \mathrm{~Pb} /{ }^{204} \mathrm{~Pb}\right)_{300}$ & 18.722 & 18.244 & & & & 18.263 & 18.390 & 18.446 & 18.311 & 18.408 & 18.243 & 18.630 & 18.599 \\
\hline$\left({ }^{207} \mathrm{~Pb} /{ }^{204} \mathrm{~Pb}\right)_{300}$ & 15.578 & 15.615 & & & & 15.608 & 15.633 & 15.630 & 15.666 & 15.654 & 15.594 & 15.611 & 15.591 \\
\hline$\left({ }^{208} \mathrm{~Pb} /{ }^{204} \mathrm{~Pb}\right)_{300}$ & 38.357 & 38.166 & & & & 38.208 & 38.302 & 38.223 & 38.590 & 38.806 & 38.277 & 38.440 & 38.490 \\
\hline
\end{tabular}

* Sr and Nd isotope data from Villaseca et al. (1999). ** Sr and Nd isotope data from Orejana et al. (2006). Uncertainties for the ${ }^{87} \mathrm{Sr} /{ }^{86} \mathrm{Sr}$ and ${ }^{143} \mathrm{Nd} /{ }^{144} \mathrm{Nd}$ ratios are 2 sigma errors in the last two digits.

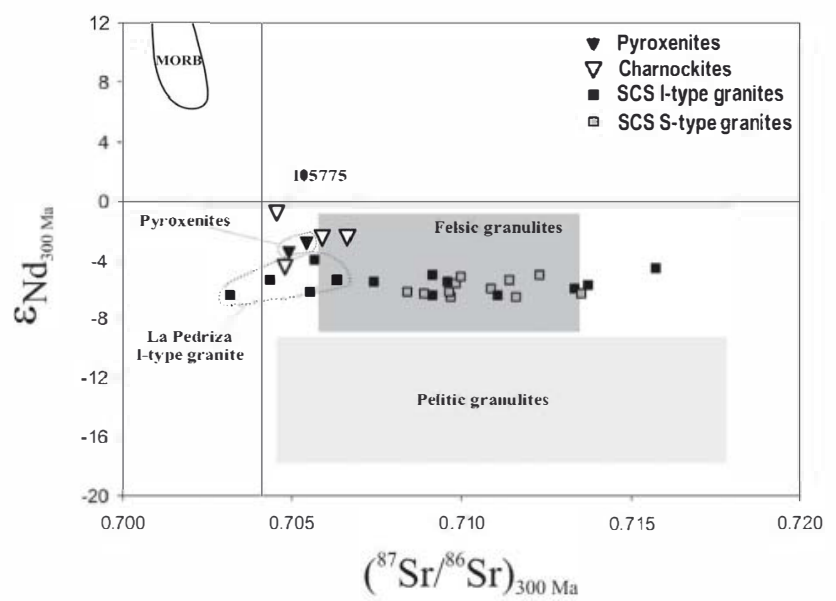

Fig. 9. Sr-Nd isotopic ratios at $300 \mathrm{Ma}$ for the SCS granulite xenoliths. Field for calc-alkaline pyroxenite xenoliths from Orejana et al. (2006). Fields for felsic and pelitic granulite xenoliths from Villaseca et al. (1999), and for the SCS Hercynian granites from Villaseca et al. (1998). Also shown is unpublished compositional data for La Pedriza I-type granites.

periments on meta-basic rocks show amphibole to be stable above $975{ }^{\circ} \mathrm{C}$ (Hacker, 1990; Springer \& Seck, 1997; Sisson et al., 2005); its stability is a function of several factors including metamorphic conditions (P-T-oxygen fugacity) and whole-rock composition. The varied chemical composition of SCS charnockites and the presence of residual Ti-F-rich phlogopite in associated peraluminous granulite xenoliths suggest that amphibole was scarce or absent in the original pre-granulitic lithotypes, which would suggest long-term residence at lower crustal levels and recrystallization under high-T granulite facies conditions.

\section{Pyroxene granulites and the SCS Hercynian granitoid plutonism}

$\mathrm{Sr}-\mathrm{Nd}-\mathrm{Pb}$ isotope ratios and multi-element and REE patterns show that many SCS charnockites are similar in composition to associated peraluminous restitic felsic granulite xenoliths. The felsic composition of these charnockites, combined with their granoblastic texture and pyroxene compositions that are similar to those of restitic pyroxenes in melting experiments, suggests that most of the SCS pyroxene-bearing granulites could be residues left after extraction of a granitic melt. Villaseca et al. (1999) and Villaseca \& Herreros (2000) suggested that the suite of garnet-bearing felsic granulite xenoliths represent residues left after extraction of granitic magma similar in composition to the peraluminous granitoids of the SCS batholith. The Hercynian age of zircon recrystallization obtained from some SCS granulite xenoliths is consistent with a genetic link to Hercynian granite magmatism (Fernández Suárez et al., 2006). The more mafic and metaluminous composition of the studied charnockite xenoliths could link these granulites to the less peraluminous, I-type SCS granites. In fact, slightly peraluminous to subaluminous amphibole-bearing granites have been described in the region (Villaseca et al., 1998; Villaseca \& Herreros, 2000). Metaluminous restite is usually in equilibrium with moderately peraluminous melt in melting experiments (e.g. Patiño Douce \& Beard, 1995; Sisson et al., 2005).

Initial Sr-Nd isotopic ratios (at $300 \mathrm{Ma}$ ) of charnockite xenoliths (excluding the most basic, cumulate-like, 105775 sample) show a range of $\varepsilon_{\mathrm{Nd}}$ from -2.6 to -4.2 and ${ }^{87} \mathrm{Sr} /{ }^{86} \mathrm{Sr}$ from 0.7051 to $\mathbf{0 . 7 0 6 6}$, values that only overlap slightly with the most isotopically primitive SCS granites (Fig. 9). Nevertheless, unpublished Sr-Nd data on SCS granites have recorded such unradiogenic Sr values in an Itype leucogranite pluton (La Pedriza massif) (Fig. 9). In addition, the granulite $\mathrm{Pb}$ isotope data presented in this work also corroborates the similarity between granulite xenoliths and outcropping Hercynian granites of I-type affinity. Figure 10 includes available $\mathrm{Pb}$ isotope data on SCS granites, mainly for the La Pedriza sector (Pérez-Soba, 1992), together with other Hercynian granites from central Spain (Los Pedroches batholith, S- and transitional-Itype granites; García de Madinabeitia, 2002). The granulite xenolith $\mathrm{Pb}$ isotopic data clearly match that of the Hercynian granite compositional field, thus reinforcing the 

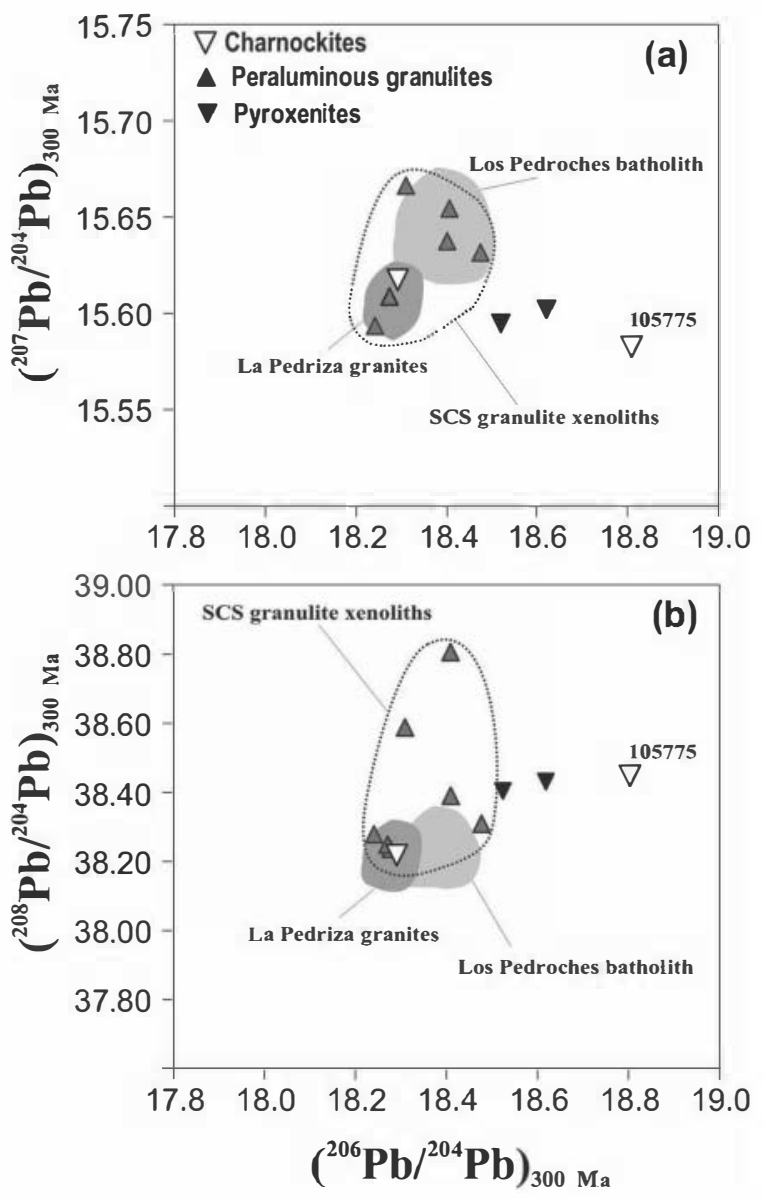

Fig. 10. Pb isotopic ratios at $300 \mathrm{Ma}$ for the SCS granulite xenoliths and calc-alkaline pyroxenites: $\mathrm{a})^{207} \mathrm{~Pb} /{ }^{204} \mathrm{~Pb}$ vs. ${ }^{206} \mathrm{~Pb} /{ }^{204} \mathrm{~Pb}, \mathrm{~b}$ ) ${ }^{208} \mathrm{~Pb} /{ }^{204} \mathrm{~Pb} v$ s. ${ }^{206} \mathrm{~Pb} /{ }^{204} \mathrm{~Pb}$. Also shown are fields for K-feldspars from Central-Iberian Hercynian granites: Los Pedroches batholith (García de Madinabeitia, 2002), La Pedriza sector (Pérez-Soba, 1992). Peraluminous granulites comprise felsic and metapelitic xenoliths.

granulite-granite connection in central Spain. A similar lower crustal derivation, based on $\mathrm{Sr}-\mathrm{Nd}-\mathrm{Pb}$ isotopic data, has been suggested for Hercynian granites of the French Massif Central (Downes et al., 1997). Most of the granulite xenoliths with pelitic natures have different $\mathrm{Sr}-\mathrm{Nd}$ isotopic ratios to the Hercynian granites from central Spain (Fig. 9 and 10) (Table 7), underlining their minor contribution to the SCS peraluminous granite batholith as has been previously stated (Villaseca et al., 1998; 1999; Villaseca \& Herreros, 2000).

\section{Conclusions}

SCS pyroxene-bearing xenoliths equilibrated at high $P-T$ conditions, mainly in the range of 900 to $1000{ }^{\circ} \mathrm{C}$ and 9 to $11 \mathrm{kbar}$. Although these ranges represent more extreme $P-T$ values, they overlap with estimates for the most abundant felsic granulites, indicating similar metamorphic conditions, and, therefore, they may have been sampled from the same depth in the lower crust.
The heterogeneity shown by SCS charnockite xenoliths implies contrasting origins. The most mafic samples could represent metamorphosed equivalents of mafic calc-alkaline magmas intruded at or near the crust-mantle boundary. Due to their spatial association with ultramafic pyroxenite xenoliths, they are interpreted as having crystallized initially as gabbroic cumulates, successively converted to granulites as they cooled. Nevertheless, the most abundant intermediate $\left(\mathrm{SiO}_{2}>52 \mathrm{wt} . \%\right)$ charnockite xenoliths could be restitic granulites after granite melt extraction; this is due to their appropriate pyroxene mineral chemistry and the strong overlap in initial $\mathrm{Sr}-\mathrm{Nd}-\mathrm{Pb}$ isotope ratios with outcropping Hercynian granites, mainly with those of I-type affinity.

If the abundances of mafic and felsic xenoliths in the SCS reflects the true abundance of these compositions in the lower crust, and if only a few of these mafic xenoliths are true cumulates from an underplating event at the crust-mantle boundary, then mantle-derived magmatism during Hercynian times in central Spain represents a minor episode of crustal accretion. This is in agreement with recent thermal modelling of the Hercynian collision by thickening of the central Iberian crust, if correct it would imply that granite magmatism does not require a significant addition of heat from mantle sources (Bea et al., 2003).

Acknowledgements: We acknowledge the assistance of Alfredo Fernández Larios and José González del Tánago for the electron-microprobe analyses in the CAI of $\mathrm{Mi}$ croscopía Electrónica (UCM). We are grateful to Hilary Downes and Dan Lux for their constructive reviews, and to Angelo Peccerillo for the editorial handling. Laser mineral analyses were carried out at the Large Scale Geochemical Facility supported by the European Community Access to Research Infrastructure action of the Improving Human Potential Programme, contract number HPRI-CT1999-00008. Pb isotope analyses have been also supported by the EU Access to Research Infrastructure action of the Improving Human Potential Programme during 2004 (Large Scale Geochemical Facility grant) and 2005 (SYNTHESYS grant under Framework Programme 6). This work is included in the objectives of, and supported by, the CGL-2004-02515 project of the Ministerio de Ciencia y Tecnología of Spain.

\section{References}

Al-Mishwat, A. \& Nasir, S.J. (2004): Composition of the lower crust of the Arabian Plate: a xenolith perspective. Lithos, 72, 54-72.

Barbero, L. \& Villaseca, C. (2000): Eclogite facies relics in metabasites from the Sierra de Guadarrama (Spanish Central System): $P-T$ estimations and implications for the Hercynian evolution. Min. Mag., 64, 815-836.

Bea, F., Montero, P., Molina, J.F. (1999): Mafic precursors, peraluminous granitoids, and late lamprophyres in the Avila batholith; a model for the generation of Variscan batholiths in Iberia. $J$. Geol., 107, 399-419. 
Bea, F., Montero, P., Zinger, T. (2003): The nature, origin, and thermal influence of the granite source layer of Central Iberia. $J$. Geol., 111, 579-595.

Beard, J.S. \& Lof gren, G.E. (1991): Dehydration melting and watersaturated melting of basaltic and andesitic greenstones and amphibolites at 1, 3 and $6.9 \mathrm{~kb}$. Petrol., 32, 365-401.

Berger, J., Féménias, O., Coussaert, N., Demaiffe, D. (2005): Magmatic gamet-bearing mafic xenoliths (Puy Beaunit, French Massif Central): P-T path from crystallisation to exhumation. Eur. J. Mineral., 17, 687-701.

Brey, G.P. \& Kölher, T. (1990): Geothermobarometry in four phase lherzolites, part II: new thermobarometers, and practical assessment of existing thermobarometers. J. Petrol., 31, 1353-1378.

Brey, G.P., Nickel, K.G., Kogarko, L. (1986): Garnet-pyroxene equilibria in the system $\mathrm{CaO}-\mathrm{MgO}-\mathrm{Al}_{2} \mathrm{O}_{3}-\mathrm{SiO}_{2}$ (CMAS): prospects for simplified ('T-independent') lherzolite barometry and an eclogite-barometer. Contrib. Mineral. Petrol., 92, 448-455.

Carignan, J., Hild, P., Mevelle, G., Morel, J., Yeghicheyan, D. (2001): Routine analyses of trace elements in geological samples using flow injection and low pressure on-line liquid chromatography coupled to ICP-MS; a study of geochemical reference materials BR, DR-N, UB-N, AN-G and GH. Geostand. Newsl., 25, 187-198.

Carrington, D.P. \& Harley, S.L. (1995): Partial melting and phase relations in high-grade metapelites: an experimental petrogenetic grid inthe KFMASH system. Contrib. Mineral. Petrol., 120, 270-291.

Castro, A., Patiño-Douce, A., Corretgé, L.G., De la Rosa, J.D., ElBiad, M., El-Hmidi, H. (1999): Origin of peraluminous granites and granodiorites, Iberian Massif, Spain: an experimental test of granite petrogenesis. Contrib. Mineral. Petrol., 135, 255-276.

Condie, K.C., Cox, J., O'Reilly, S.Y., Griffin, W.L., Kerrich, R. (2004): Distribution of high field strength and rare elements in mantle and lower crustal xenoliths from the southwestern United States: the role of grain-boundary phases. Geochim. Cosmochim. Acta, 68, 3919-3942.

Downes, H. (1993): The nature of the lower continental crust of Europe: petrological and geochemical evidence from xenoliths. Phys. Earth Planet. Inter., 79, 195-218.

Downes, H., Shaw, A., Williamson, B.J., Thirlwall, M.F. (1997): $\mathrm{Sr}, \mathrm{Nd}$ and $\mathrm{Pb}$ isotopic evidence for the lower crustal origin of Hercynian granodiorites and monzogranites, Massif Central, France. Chem. Geol., 136, 99-122.

Dunn, A., Reynolds, P.H., Clarke, D.B., Ugidos, J.M. (1998): A comparison of the age and composition of the Shelbume dyke, Nova Scotia, and the Messejana dyke, Spain. Canad. J. Earth Sci., 35, 1110-1115.

Ellis, D. J. (1980): Osumilite-sapphirine-quartz granulites from Enderby Land, Antarctica: P-T conditions of metamorphism, implications for garnet-cordierite equilibria and the evolution of the deep crust. Contrib. Mineral. Petrol., 74, 201-210.

Fernández Suárez, J., Arenas, R., Jeff ries, T.E., Whitehouse, M.J., Villaseca, C. (2006): A U-Pb geochronological study of zircons from a lower crustal xenolith of the Spanish Central System: a record of Iberian lithospheric evolution from Neoproterozoic to the Triassic. J. Geol., 114, 471-483.

García de Madinabeitia, S. (2002): Implementación y aplicación de los análisis isotópicos de $\mathrm{Pb}$ al estudio de las mineralizaciones y la geocronología del área Los Pedroches-Alcudia (Zona CentroIbérica). Ph D. Universidad del País Vasco, Bilbao, 217 p.
Hacker, B.R. (1990): Amphibolite-facies-to-granulite-facies reactions in experimentally deformed, unpowdered amphibolite. Amer. Mineral., 75, 1349-1361.

Harley, S.L. (1984): An experimental study of partitioning of $\mathrm{Fe}$ and $\mathrm{Mg}$ between gamet and orthopyroxene. Contrib. Mineral. Petrol., 86, 359-373.

Irving, A.J. \& Frey, F.A. (1984): Trace element abundances in megacrysts and their host basalts; constraints on partition coefficients and megacrysts genesis. Geochim. Cosmochim. Acta, 48, 1201-1221.

Kretz, R. (1983): Symbols for rock forming minerals. Amer Mineral., 68, 277-279.

Le Maitre, R.W., Bateman, P., Dudek, A., Keller, J., Lameyre, J., Le Bas, M.J., Sabine, P.A., Schmid, R., Sorensen, H., Streickeisen, A., Wooley, A.R., Zannetin, B. (1989): A classification of igneous rocks and glossary of terms. Blackwell, Oxford, $193 \mathrm{p}=\mathrm{p}$.

Loock, G., Stosh, H. G., Seck, H. A. (1990): Granulite facies lower crustal xenoliths from the Eifel, West Germany: petrological and geochemical aspects. Contrib. Mineral. Petrol., 105, 25-41.

McDonough, W.F. \& Sun, S.S. (1995): The composition of the Earth. Chem. Geol., 120, 223-253.

Montel, J.M. \& Vielzeuf, D. (1997): Partial melting of metagreywackes, part II. Compositions of minerals and melts. Contrib. Mineral. Petrol., 128, 176-196.

Moreno-Ventas, I., Rogers, G., Castro, A. (1995): The role of hybridization in the genesis of Hercynian granitoids in the Gredos Massif, Spain: inferences from Sr-Ndisotopes. Contrib. Mineral. Petrol., 120, 137-149.

Nair, R., \& Chacko, T. (2002): Fluid-absent melting of high-grade semipelites: $P-T$ constraints on orthopyroxene formation and implications for granulite genesis. J. Petrol., 43, 2121-2142.

Newton, R.C. \& Perkins, D.I. (1982): Thermodynamic calibration of geobarometers based on the assemblages garnet-plagioclaseorthopyroxene (clinopyroxene)-quartz. Amer. Mineral., 67, 203-222.

Nuez, J., Ubanell, A.G., Villaseca, C. (1982): Diques lamprofíricos norteados con facies brechoidales eruptivas en la región de La Paramera de Ávila (Sistema Central Español). Cuad. Lab. Xeol. Laxe, 3, 53-73

Orejana, D., Villaseca, C., Paterson, B.A. (2006): Geochemistry of pyroxenitic and homblenditic xenoliths in alkaline lamprophyres from the Spanish Central System. Lith $\bullet$, 86, 167-196.

Patiño Douce, A.E. \& Beard, J.M. (1995): Dehydration-melting of biotite gneiss and quartz amphibolite from 3 to $15 \mathrm{kbar} . J$. Petrol., 36, 707-738.

Patiño Douce, A.E. \& McCarthy, T.C. (1998): Melting of crustal rocks during continental collision and subduction. In "When continents collide: Geodynamics and geochemistry of ultrahighpressure rocks" (B.R. Hacker and J.G. Liou, eds.). Kluwer Academic Publishers. 27-55.

Pérez-Soba, C. (1992): Petrología y geoquímica del macizo granítico de La Pedriza, Sistema Central Español. Ph D. Universidad Complutense, Madrid, $225 \mathrm{p}$.

Perini, G., Cebriá, J.M., López-Ruiz, J.M., Doblas, M. (2004): Permo-Carboniferous magmatism in the variscan belt of Spain and France: implications on mantle sources. in: "PermoCarboniferous magnatism and rifting in Europe", M. Wilson, E.R. Neumann, G.R. Davies, M.J. Timmerman, M. Heeremans, B. Larsen, eds., Geol. Soc. London Spec. Publ. 223, 415-438. 
Pinarelli, L. \& Rottura, A. (1995): Sr and Nd isotopic study and RbSr geochronology of the Béjar granites, Iberian Massif, Spain. Eur. J. Mineral., 7, 577-589.

Pride, C. \& Muecke, G.K. (1981): Rare earth element distributions among coexisting granulite facies minerals, Scourian Complex, NW Scotland. Contrib. Mineral. Petrol., 76, 463-471.

Reid, M.R. (1990): Ionprobe investigation of rare earth element distribution and partial melting of metasedimentary granulites. in: "Granulites and crustal evolution", D. Vielzeuf, $\mathrm{Ph}$. Vidal, eds., Kluwer Acad. Publ., 507-522.

Reyes, J., Villaseca, C., Barbero, L., Quejido, A.J., Santos Zalduegui, J.F. (1997): Descripción de un método de separación de $\mathrm{Rb}, \mathrm{Sr}, \mathrm{Sm}$ y Nd en rocas silicatadas para estudios isotópicos. Congr. Ibéric Ge@quim., I, 46-55.

Rogers, N.W. \& Hawkesworth, C.J. (1982): Proterozoic age and cumulate origin for granulite xenolith, Lesotho. Nature, 299, 409-413.

Singh, J. \& Johannes, W. (1996): Dehydration melting of tonalites. Part II. Compositions of melts and solids. Contrib. Mineral. Petrol., 125, 26-44.

Sisson, T.W., Ratajeski, K., Hankins, W.B., Glazner, A.F. (2005): Voluminous granitic magmas from common basaltic sources. Contrib. Mineral. Petrel., 148, 635-661.

Skjerlie, K.P. \& Johnston, A.D. (1996): Vapour-absent melting from 10 to $20 \mathrm{kbar}$ of crustal rocks that contain multiple hydrous phases: implications for anatexis in the deep to very deep continental crust and active continental margins. J. Petrel., 37, 661691.

Soto, J.I. \& Soto, V.M. (1995): PTMAFIC: software package for thermometry, barometry, and activity calculations in mafic rocks using an IBM-compatible computer. Comput. Geoscie., 21, 619652.

Springer, W. \& Seck, H.A. (1997): Partial fusion of basic granulites at 5 to 15 kbar: implications for the origin of TTG magmas. Contrib. Mineral. Petrol., 127, 30-45.

Storkey, A.C., Hernnann, J., Hand, M., Buick, I.S. (2005): Using in-situ trace-element deterninations to monitor partial-melting processes. J. Petrol., 46, 1283-1308.

Sun, S.S. \& McDonough, W.F. (1989): Chemical and isotopic systematics of oceanic basalts; implications for mantle composition and processes. Geol. Soc. London, Spec. Publ., 42, 313-345.

Ulianov, A., Kalt, A., Pettke, T. (2006): Aluminous websterite and granulite xenoliths from the Chyulu Hills volcanic field, Kenya: gabbro-troctolitic cumulates subjected to lithospheric foundering. Contrib. Mineral. Petrol., 152, 459-483.

Upton, J., Aspen, P., Hinton, W. (2001): Pyroxenite and granulite xenoliths from beneath the Scottish Northern Highlands
Terrane: evidence for lower-crust/upper-mantle relationships. Contrib. Mineral. Petrol., 142, 178-198.

Villaseca, C. \& Herreros, V. (2000): A sustained felsic magmatic system: the Hercynian granitic batholith of the Spanish Central System. Trans. R. Sec. Edinburgh: Earth Sci., 91, 207-219.

Villaseca, C., Barbero, L., Rogers, G. (1998): Crustal origin of Hercynian peraluminous granitic batholiths of central Spain: petrological, geochemical and isotopic ( $\mathrm{Sr}, \mathrm{Nd}$ ) constraints. Lithos, 43, 55-79.

Villaseca, C., Downes, H., Pin, C., Barbero, L. (1999): Nature and composition of the lower continental crust in central Spain and the granulite-granite linkage: inferences from granulitic xenoliths. J. Petrel., 40, 1465-1496.

Villaseca, C., Martín Romera, C., De la Rosa, J., Barbero, L. (2003): Residence and redistribution of REE, Y, $\mathrm{Zr}$, Th and $\mathrm{U}$ during granulite-facies metamorphism: behaviour of accessory and major phases in peraluminous granulites of central Spain. $\underline{\text { Chem. }}$. Geol., 200, 293-323.

Villaseca, C., Orejana, D., Pin, C., López García, J.A., Andonaegui, P. (2004): Le magmatisme basique hercynien et post-hercynien du Système Central Espagnol: essai de caractèrisation des sources manteliques. C. R. Geosciences, 336, 877-888.

Villaseca, C., Orejana, D., Paterson, B.A. (2007): Zr-LREE rich minerals in residual peraluminous granulites, another factor in the origin of low Zr-LREE granitic melts? Lithos 96, 375-381.

Watson, E.B., Wark, D.A, Thomas, J.B. (2006): Crystallization thermometers for zircon and rutile. Contrib. Mineral. Petrol., 151, 413-433.

Wells, P.R.A. (1977): Pyroxene thermometry in simple and complex systems. Contrib. Mineral. Petrol., 62, 129-139.

Witt-Eickschen, G. \& Seck, H.A. (1991): Solubility of Ca and Al in orthopyroxene from spinel peridotite: an improved version of an empirical geothermometer. Contrib. Mineral. Petrol., 106, 431-439.

Wood, B. J. \& Banno, S. (1973): Gamet-orthopyroxene and gametclinopyroxene relationships in simple and complex systems. Contrib. Mineral. Petrol., 42, 109-124.

Zack, T., Moraes, R., Kronz, A. (2004): Temperature dependence of $\mathrm{Zr}$ in rutile: empirical calibration of a rutile thermometer. Contrib. Mineral. Petrol., 148, 471-488.

Received 19 ct ber 2006

Modified version received 12 April 2007

Accepted 7 Mai 2007 